\title{
Türkiye Su Ürünleri Yetiştiriciliği Sektörünün Rekabetçilik Düzeyine Akademisyenlerin Bakış Açısı ${ }^{1}$
}

\author{
Görkem Dalkırana ${ }^{*}$, Fatma Zehra Tan ${ }^{a}$ \\ a,b Karabük Üniversitesi İşletme Fakültesi, Karabük.
}

\section{$\ddot{O} z$}

Ülkemizin en hızl büyüyen sektörlerinden birisi de su ürünleri yetiştiriciliği sektörüdür. 1970'li yıllardan bu yana sektör hem kapasite, hem teknolojik imkanlar, hem de insan kaynakları bakımindan oldukça ilerleme kaydetmiş ve en nihayetinde 2016 yll istatistiklerine göre ülkemiz toplam su ürünleri üretiminin \%40'ın karşılar hale gelmiştir. Gelecekte de büyümesini sürdürmesi öngörülen bu sektörün rekabetçilik düzeyinin belirlenmesi ve buna ilişkin yönetimsel stratejilerin geliştirilmesi gerektiği düşünülmektedir. Bu çalşmada su ürünleri ve balıkçllk ile ilgili araştırma birimlerinde görev alan akademisyenlerin sektörün rekabetçilik düzeyine bakış açılarının tespit edilmesi amaçlanmıştır. Çalışmada Porter tarafından geliştirilen ve rekabetçilik düzeyinin açıklanmasında en yaygın model olarak kabul edilen Elmas Modeli kullanılmıştır. Çalışmanın sonuçlarına göre rekabeti etkileyen kuvvetlerin en önemlisi akademisyenlere göre sırasıyla Firmalar Arası Rekabet (3,64 $\pm 0,12)$, İkame Ürünlerin Etkisi $(3,57 \pm 0,14)$, Tedarikçilerin Gücü $(3,33 \pm 0,11)$, Alccların Gücü $(3,17 \pm 0,11)$ ve Sektöre Yeni Giriş $(2,63 \pm 0,12)$ olarak belirlenmiştir. Bunun yanı sıra akademisyenlere göre sektördeki bir firmanın seçmesi gereken jenerik strateji yaklaşımının Farklılaştırma olması gerektiğgi anlaşılmıştır. Rekabeti şekillendiren faktörlerin en önemlisinin firmalar arası rekabet olduğu düşünüldü̆g̈̈nde, rekabet gücünün artırmak isteyen bir firma için ürün veya üretim sürecini farklılaştırllması önerilebilir. Ayrıca

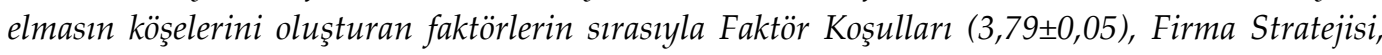
Yapı ve Rekabet $(3,60 \pm 0,06)$, Şans $(3,60 \pm 0,09)$, Talep Koşulları $(3,13 \pm 0,06)$, Devlet $(3,06 \pm 0,06)$ ve İlgili ve Destek Endüstriler $(2,78 \pm 0,07)$ olduğu görülmektedir. Buna göre akademisyenlerin bakış

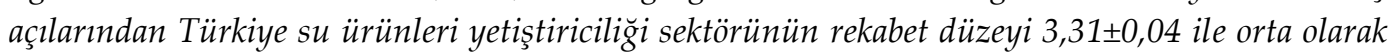
tespit edilmiştir.

Anahtar Kelimeler: Su ürünleri yetiştiriciliği, Rekabetçilik, Porter, Elmas Modeli

\section{The Perspectives of Academicians on Competitiveness Level of Turkish Aquaculture Sector}

\begin{abstract}
One of the rapid growing sectors of Turkey is also aquaculture sector. From 1970s, the sector has got ahead in terms of its capacity, technologically and human resources, and according to statistics of 2016, it has finally supplied $40 \%$ of total fisheries production in Turkey. It is thought that it needs to determine the competitiveness level of the sector which it will continue its growth in future, and it is necessary to develop administrative strategies related to this. In this study, it was aimed that being determined of perspective of academicians on competitiveness level of Turkish aquaculture sector. Porter's Diamond Model, which is accepted as most common model for explaining competitiveness level and developed by Michael E. Porter, was used in this study. According to result of this study, Porter's five forces are Intensity of competitive rivalry $(3,64 \pm 0,12)$, Threat of substitute products or services $(3,57 \pm 0,14)$, Bargaining power of suppliers $(3,33 \pm 0,11)$, Bargaining power of buyers $(3,17 \pm 0,11)$ and Threat of new entrants $(2,63 \pm 0,12)$ respectively. In addition to this, according to academicians, it has been understood that the generic strategy approach of a firm on the sector should be Differentiation. When it is considered that the

${ }^{1}$ Bu çalışma Karabük Üniversitesi Sosyal Bilimler Enstitüsü İşletme Ana Bilim Dalında yürütülen "Türkiye Su Ürünleri Yetiştiriciliği Sektörünün Uluslararası Rekabetçilik Düzeyinin Belirlenmesi ve Sektörün Farklı Paydaşları Açısından Değerlendirilmesi" başlıklı doktora tez çalışmasından üretilmiştir.
\end{abstract}

*Yazışma adresi. Email: gorkemdalkiran@gmail.com 
most important force of Porter's five forces is intensity of competitive rivalry, it may be suggested to differentiate the product or production process for a firm that wants to increase its competitive power. Moreover, the corners of diamond model are Factor conditions $(3,79 \pm 0,05)$, Firm strategy, structure and rivalry $(3,60 \pm 0,06)$, The Role of Chance $(3,60 \pm 0,09)$, Demand conditions $(3,13 \pm 0,06)$, The Role of Government $(3,06 \pm 0,06)$ and Related and supporting industries $(2,78 \pm 0,07)$ respectively. As a result of this study, the competitiveness level of Turkish aquaculture sector from academicians point of view is determined as 3,31 $\pm 0,04$ (middle).

Keywords: Aquaculture, Competitiveness, Micheal E. Porter, Diamond Model

\section{GİRIŞ}

Dünya nüfusundaki artışla birlikte artan protein ihtiyacının karşılanmasında balıkçılık ve su ürünleri yetiştiriciliği değerlendirilmesi gereken önemli bir fırsattır (Sarıözkan, 2016: 16). Ancak doğal kaynaklar üzerindeki aşırı ve bilinçsiz avcılık baskısı, iklimsel değişmeler, teknolojik ilerlemeler ve balıkçı filolarındaki niteliksel ve niceliksel artışlar gibi nedenlerden ötürü avcılık yoluyla elde edilen miktarlarda yıldan yıla yaşanan azalma, bu protein açı̆̆ının karşılanmasında su ürünleri yetiştiriciliğini daha da ön plana çıkarmaktadır. Nitekim istatistiklere bakıldığında son 15 yılda su ürünleri yetiştiriciliğinden elde edilen üretim miktarının 79 bin tondan 235 bin tona çıkmak suretiyle 3 kat arttığı, yetiştiricilik ürünlerinin toplam üretimi karşılama oranının ise \%13'lerden, \%40'lara çıtığ görülmektedir (TÜİK, 2016). Ayrıca Türkiye, su ürünleri yetiştiriciliği üretimi bakımından Avrupa Birliği üye ülkeleri ile karşılaştırıldığında İspanya'dan sonra ikinci sırada, Avrupa kıtası ülkeleri arasında ise Norveç ve İspanyanın ardından üçüncü sıradadır (FAO, 2016). Tüm bu gelişmeler doğrultusunda Türkiye su ürünleri ihracatında da önemli ilerlemeler yaşanmış ve en nihayetinde ülkemiz toplam su ürünleri üretiminin yaklaşık \%20'sini ihraç eder konuma gelmiştir. En çok ihracat yapılan ülkeler sıralamasında ilk üçte Hollanda, Almanya ve İtalya bulunmaktadır. Bu üç ülkeye yapılan ihracat, toplam ihracatın \%55'ini oluşturmaktadır (TÜİK, 2016).

Sanayi toplumundan bilgi toplumuna geçiş ile birlikte bilgi ve iletişim olanaklarının artması tüm dünyada ekonominin de küresel bir kimlik kazanmasına neden olmuştur. Böylelikle rekabet kavramı hem firma, hem ilgili endüstri ve hem de ülke düzeyinde her kesim için oldukça önemli bir hale gelmiş, konunun önemi dolayısıyla da rekabetçilik ve rekabet gücü kavramları yönetim üzerine yapılmış çalışmalarda sıklıkla yer almıştır. Özellikle stratejik yönetim konusunda rekabetçilik konusu oldukça önemli bir yer tutmaktadır. Çünkü modern stratejik yönetim görüşünde, rekabet üstünlügü bulunmayan ve rakiplerinin kendi üstünlüklerini ve verimliliklerini devamlı arttırmaları sonucu verimliliğini her geçen gün kaybeden işletmelerin piyasadan çekileceği ileri sürülmektedir. Bu nedenle modern stratejik yönetim düşüncesi işletmelerin uzun dönemde yaşamlarını sürdürebilmeleri adına rekabet üstünlüğü elde etmek için uğraşmaları gerektiğini vurgulamakta, rekabet üstünlügünün de ancak değer yaratan stratejilerin geliştirmesi ile mümkün olduğu belirtilmektedir (Ülgen ve Mirze, 2013: 32). Strateji geliştirecek kişi ya da birimin yapacağı ilk iş ise, özünde rekabeti anlamak ve onunla başa çıkmaktır (Porter, 2013: $55)$. 
Türk Dil Kurumu, rekabeti “Aynı amacı güden kimseler arasındaki çekişme, yarışma, yarış" olarak tanımlamaktadır. İşletmecilik disiplininde ise rekabet "İki veya daha fazla işletmenin belirli bir tüketici grubunu hedefleyerek belirli bir üretime ve/veya hizmete ilişkin etkinlik ve verimliliğini arttırarak rakiplerine üstünlük sağlama çalışması" olarak tanımlanmıştır (Koç ve Özbozkurt, 2014: 86). Rekabetçilik, rekabet gücü gibi kavramlar üzerinde, değişik disiplinlerdeki bilim adamlarının ve kurumların çok yönlü yaklaşımları ve konuyu farklı açıdan ele almaları nedeniyle ortak bir görüşe varılamamaktadır. Endüstriyel Rekabet Komisyonu rekabet gücünü “Ülkelerin serbest ve yerleşmiş pazar koşulları altında vatandaşların reel getirilerini arttırmaya çalışırken, aynı anda ürettiği ürün ve hizmetleri uluslararası piyasalara sunabilmeleri ve başarılı olabilmeleri" şekilde tanımlarken (Çivi, 2001: 22), Dünya Ekonomik Formu ise "Bir ülkenin verimlilik seviyesini belirleyen faktörlerin, politikaların ve kurumların bir karması" olarak ele almakta, Yönetim Geliştirme Enstitüsü de “Devletin, ülkelerdeki işletmelere daha fazla değer yaratabilmelerini sağlayacak, halkına ise yüksek refaha ulaşmalarını mümkün kılacak bir ortam sunabilme yeteneği" olarak tanımlamaktadır (Gökmenoğlu vd., 2012: 5).

Rekabet gücü akademik olarak firma ve endüstri düzeyinde olmak üzere mikro ve ülke düzeyinde olmak üzere ise makro düzeyde incelenmekte, mikro düzeyli yaklaşımda işletmelerin arasındaki rekabet ve bu rekabetin hem ulusal hem de uluslararası seviyedeki etkileri incelenirken, makro düzeyde ise ülkenin uluslararası rekabetçilik konumuna odaklanılmaktadır (Çivi, 2001: 22).

Esasen rekabetçilik düzeyinin açılanmasında sektörde faaliyet gösteren firmalardan elde edilen bilgiler kullanılsa da, sektörde bütüncül bir bakış açısı yakalayabilmek için, tedarikçiler, alıcılar, sivil toplum kuruluşları, devlet, araştırma kuruluşları gibi sektörün diğer aktörlerinin de rekabette etki eden faktörler olduğu bilindiğinden (Porter, 2013: 64) rekabet düzeyinin belirlenmesinde diğer paydaşların bakış açılarının ne olduğunun tespit edilmesi oldukça önemli gözükmektedir. Bu çalışmada ülkemizin önemli sektörlerinden birisi olan su ürünleri yetiştiriciliği sektörünün rekabetçilik düzeyini balıkçılık ve su ürünleri yetiştiriciliği konusunda bilimsel çalışmalar yapan ve sektöre nitelikli teknik insan kaynağı yetiştirilmesi konusunda öncül kuruluşlar olan üniversiteler ve araştırma enstitülerinde görev alan akademisyenlerin bakış açısıyla açıklamak amaçlanmıştır.

\section{LITERATÜR}

Rekabet iki veya daha fazla işletmenin belirli bir tüketici grubunu hedeflemek suretiyle üretiminin veya hizmetinin verimliliğini arttıracak şekilde adımlar atarak diğer işletmelere karşı bir üstünlük sağlaması olarak tanımlanabilir. Rekabet gücü ise bir ülkedeki bir sektörün diğer ülkelerdeki aynı sektöre göre daha yüksek gelir ya da istihdam yaratabilme gücü olarak ifade edilebilir (Koç ve Özbozkurt, 2014: 86).

Uluslararası rekabet gücünün açıklanmasında geleneksel (iktisadi bağlam) ve modern yaklaşımlar (işletme iktisadı bağlamı) olmak üzere iki temel yaklaşımın

\footnotetext{
${ }^{1}$ http://tdk.gov.tr/index.php?option=com_gts\&view=gts (Erişim tarihi 15.11.2016)
} 
olduğunu söylemek mümkündür. Merkantilizm, Adam Smith'in Mutlak Üstünlükler Yaklaşımı, Karşılaştırmalı Üstünlükler Yaklaşımı, Faktör Donanımı, Ürün Döngüsü gibi yaklaşımlar geleneksel yaklaşımlar arasında yer almakta ve genel olarak bu teoriler uluslararası rekabeti ülkelerin sahip oldukları doğal ve fiziki kaynaklara dayanarak açıklamaya çalışmaktadırlar. Geleneksel yaklaşımlar bir ülkenin karşılaştırmalı üstünlüklere sahip olduğu malların ve hizmetlerin üretimine kaynak ayırması durumunda ticaretten gelir sağlayabilmesi konusunun altını çizmektedir. Kısacası yapı içerik ve bakış açısı bakımından bu teorilerin rekabet gücü konusunu makro ve mikro düzeyde ele alma, mevcut önerilerin yetersizliklerine vurgu yaparak yeni bakış açılarını ortaya koymaya çalışma, rekabet gücünü teşkil eden kaynakların görece üstünlüklerini vurgulama, rekabet gücü mekanizmasını arz-talep mekanizması çerçevesinde ele alma, rekabet üstünlügünü ölçek ekonomisi ile ilişkilendirme, farklılaştırma yeteneği, yerel verimlilik göstergesi ve refah yaratabilme kabiliyeti ile eşdeğer görme şeklinde incelemektedir. Klasik teoriler bir ülkenin ihracatında önemli bir belirleyici olarak karşılaştırmalı üstünlüklerin önemini vurgulamışlar, modern teoriler ise rekabet üstünlüğ̈̈nün önemine yoğunlaşmışlardır. Çalışmalar her bir ülkenin rekabetçiliğinin onun rekabet faktörlerinin benzersiz bir karışımına bağlı olduğunu göstermiştir (Çivi, 2001: 24-28; Gökmenoğlu vd., 2012: 6; Rodrigues ve Kahn, 2015: 19).

Oysa yalnızca makroekonomik değişkenler, emek, devlet politikaları veya yönetim tekniklerinin tek başına rekabet avantajlarının belirleyicisi olarak görülmesinin doğru sonuçlar vermeyeceği düşünülmektedir (Bulu vd., 2006: 53). Bu nedenle rekabet gücünün açıklanmasında başka bir paradigmaya ihtiyaç duyulmuştur.

Michael E. Porter 1990 yılında daha geçerli bir bakış açısı yakalayabilmek için yayınladığı çalışmasında, rekabetçiliğin bu etkenlerden etkilendiğini ancak bazı durumlarda bu faktörlerin yoğun olmasının büyümenin önünde engel teşkil edebildiğini belirtmiştir. Dolayısıyla Porter bu çalışmasında geleneksel rekabetçilik teorilerini eleştirerek, bir ülkenin ulusal refahın miras kalan bir unsur olmaktan çok yaratılan bir durum olduğunu ve bir ülkenin rekabetçiliğini endüstriyel yenilik ve gelişim kapasitesi ile ilişkili oluğunu belirtmiş ve bir model geliştirmiştir. Bu kavramın açıklanması noktasında genel olarak kabul edilen bu model, Michael E. Porter'in önermiş olduğu ve "Elmas Modeli" olarak adlandırdığı modeldir.

Literatür incelendiğinde rekabet gücü kavramında tüm araştırmacıların ya Porter'in bu modelini başlangıç noktası olarak aldıkları ya da Porter'in modelini başlangıç noktası alan ve modeli eleştiren araştırmacıların çalışmalarını eleştirerek mevcut modellerin iyileştirilmesi veya genişletilmesi şeklinde çalışmalar yürütüldüğü gözlemlenmektedir (Gökmenoğlu v.d, 2012: 10).

$\mathrm{Bu}$ çalışmada araştırmanın amacı göz önüne alınarak literatürde rekabetçilik düzeyi ve rekabet gücü üzerine yapılmış çalışmalar ışığında teorik arka plan olarak Michael E. Porter (1990) tarafından geliştirilen ve uluslararası rekabet gücünü açıklayan modeller arasında açıklayıcılık seviyesinin en yüksek olduğu kabul edilen Elmas Modeli kullanılmıştır. 


\subsection{Porter'ın Elmas Modeli}

Michael E. Porter 1990 yılında yayımlamış olduğu Ulusların Rekabet Üstünlüğü adlı kitabında Elmas Modeli olarak adlandırdığ 1 bu model, bir endüstrinin rekabet üstünlügünün kıyaslanmasında kullanılan ve bazı ülkelerin diğerlerine kıyasla bazı endüstrilerde neden daha başarılı olduklarını gösteren en iyi model olarak gösterilmektedir. Elmas modeli, işletmeler arasındaki rekabet anlayışını değiştiren bir paradigmayı açıklamakta ve bazı endüstri ve ülkelerin uluslararası pazarda neden diğerlerine kıyasla rekabet üstünlüğü elde edebildiği sorusuna cevap bulmaya çalışmaktadır (Mboya ve Kazungu, 2015: 129).

Porter (1990), ABD, Almanya, Japonya, Danimarka, İtalya, İsveç, Birleşik Krallık, Güney Kore ve Singapur olmak üzere 10 ülkenin 100'den fazla sektör veya endüstrisini ele almak suretiyle ulusal rekabet avantajlarının belirleyicilerini sistematik olarak ortaya koyan küresel rekabet unsurlarını bir sistem yaklaşımı içinde analiz etmiş ve bir model geliştirmiştir. Ülkelerin rekabet gücünü araştırdığg ve Elmas Modeli olarak adlandırılan bir teorik yapıda tanımladığı bu modelde, ülkelerin rekabetçi üstünlüklerinin arttırılması için dört ana faktörün (faktör koşulları, talep koşulları, ilgili ve destekleyici endüstrilerin varlığı ve işletme stratejileri) dikkate alınması gerektiğini belirtmiş ve elmasın dört köşesini oluşturmuştur (Şekil 1). Bu dört faktörün yanı sıra devlet politikaları ve şans faktörü de elmasın dışında kalmakla birlikte ülke rekabet gücüne etki eden faktörler olarak ele alınmaktadır (Porter, 1990: 127). Porter (1990), geliştirdiği Elmas Modeli sayesinde bazı ulusların neden diğerlerine göre belirli sektörlerde daha rekabetçi olduğu sorusuna cevap aramış ve bir sektördeki ulusal rekabet gücünü etkileyen faktörlerin ilişkilendirilmesini esas almıştır (Bulu, Eraslan ve Kaya, 2006: 53, Koç ve Özbozkurt, 2014: 88).

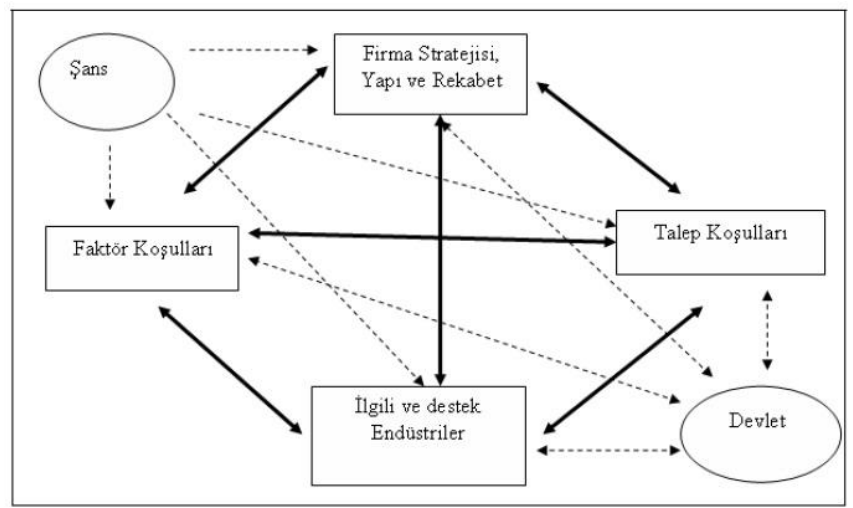

Şekil 1. Porter'in Elmas Modeli (Porter, 1990, s:127).

\subsubsection{Faktör Koşulları}

Geleneksel iktisat teorilerinde faktör koşulları doğal kaynaklar, emek, sermaye gibi bir ülkenin üretim faktörlerini ifade etmektedir. Klasik teoriler, bir ülkenin bu faktörlere sahip olmasının sektörel rekabette başarılı olunmasının ana faktörü olarak kabul eder ve bu kaynakların verimli kullanılmasının o ülkeye ulusal rekabet gücünü de beraberinde getireceğini savunur. Oysa Porter, üretim faktörlerinin miras bırakılmadığını, ülkelerin kendilerinin yaratmış olduğu unsurlar olduğunu savunur. 
Faktör koşulları aşağıda açıklandığı şekliyle birkaç alt kategoride gruplandırılabilir (Porter, 1990:74-75):

İnsan Kaynakları: İş gücünün niteliği, kalitesi, maliyetleri, erişilebilirliği ve yeteneği ile ifade edilmektedir.

Fiziksel Kaynaklar: Bir ülkedeki arazi, su, yeraltı kaynakları, iklim, hammadde, enerji ve güç kaynaklarının durumu, miktarı, maliyeti ve kalitesi ile ifade edilmektedir.

Bilgi Kaynakları: Üretilen mal ve hizmetlerle ilgili bilimsel, teknik ve pazar bilgisi ile ifade edilmektedir. Bilgi kaynakları üniversitelere, devlet araştırma enstitülerine, özel araştırma kuruluşlarına, devlet istatistik kurumlarına, bilimsel literatürün varlığına, Pazar araştırması raporları ve veri tabanlarına vb. bağlıdır.

Sermaye Kaynakları: Bir ülkedeki finansal sermayenin miktar ve maliyetleri ile ifade edilmektedir.

Altyapı: Taşıma sistemleri, iletişim sistemleri, para transferleri, sağlık vb unsular da dahil olmak üzere rekabeti etkileyen mevcut alt yapıların maliyeti, tipi ve kalitesi ile ifade edilmektedir.

Uluslararası pazarda rekabet gücüne sahip olmak isteyen bir ülkenin kalkınmasının o ülkenin faktör koşullarına göre şekillendirilmesi gerektiği söylenmektedir (Koç ve Özbozkurt, 2014: 88).

\subsubsection{Talep Koşulları}

Bir endüstrideki ulusal rekabet üstünlüğünün ikinci esas belirleyicisi endüstrinin ürün ya da hizmetlerinin yerel talep koşullarıdır. Yerel talep koşulları Porter (1990)'ın çalışmasında incelenen neredeyse tüm endüstrilerde etkilidir. Yerel talebin üç esas özelliği önemlidir. Bunlar yerel talebin niteliği, yerel talebin büyüklüğü ve genişleme modeli ve bir ülkenin yerel tercihlerinin yabancı pazarlara iletildiği mekanizmalar (yurt içi talebin uluslararasılaştırılması) olarak ifade edilebilir (Porter, 1990: 86).

Yerel talebin niteliği: Bir ürünün yerel talebi uluslararası talebe göre daha fazla ise, yerel firmaların yerel pazarı daha fazla önemsemesinden dolayı rekabet avantajı oluşmaktadır.

Yerel talebin büyüklü̆̆̈̈̈ ve genişleme modeli: Bir ürünün yerel talebinin fazlalığ1 nedeniyle oluşan rekabet, işletmelerin teknolojilerini sürekli yenilemelerini ve verimlilik artışı yaratacak yenilik arayışını tetiklemektedir.

Yurt içi talebin uluslararasılaştırılması: Yoğun olan yurt içi talebin uluslararası hale gelmesi, işletmelerin uluslararası hareketleri takip etmesine neden olmaktadır.

Talep koşulları ile ifade edilmek istenen şey aslında talebin büyüklügünden ziyade talebin kalitesidir. Yeni veya gelişmiş ürünleri talep eden tüketicilerin varlığı, o pazarda faaliyet gösteren işletmelerin yenilikçi ve yaratıcı yanlarının arttırılmasına yönelik tedbirler almasına neden olacağından, uluslararası pazarda da bu yenilikçi ürünler ile rekabet avantajı elde edileceği vurgulanmaktadır. 


\subsection{3. İlgili ve Destekleyici Endüstriler}

Bir endüstrideki ulusal rekabet avantajının üçüncü belirleyicisi ise uluslararası rekabet yaratan ilgili ve destekleyici endüstrilerin varlığıdır. Bu ilgili ve destekleyici endüstriler sektördeki firmalara hızlı ve maliyet-etkin girdi sağlayarak rekabet avantajı sağlayabilirler. Ortak müşteriler ve teknoloji gibi yatay veya tedarikçi-alıcı şeklinde dikey olmak üzere birbirine bağlı bu tür sektörlerin tümüne kümelenme adı verilmekte ve bu kümelenmelerin varlığı ile de ülke endüstrisinin uluslararası pazarda rekabet avantajı elde etmesine olanak sağlamaktadır (Gökmenoğlu vd., 2012: 13).

\subsubsection{Firma Stratejisi, Yapı ve Rekabet}

Bir endüstrideki ulusal rekabet avantajını belirleyen dördüncü faktör iç rekabetin doğası olduğu kadar firmaların oluşturulması, düzenlenmesi ve yönetilmesinin de oluşturduğu içeriktir. Çünkü firmalar nasıl oluşturulur, organize edilir ve yönetilirlerse ulusal ve uluslararası rekabet de buna göre şekillenir. Bir endüstrideki firmaların amaçları, stratejileri ve organizasyon şekilleri ülkelere göre farklılık göstermektedir. Dolasıyla her bir sektöre ya da firmaya uyabilecek standart bir yönetim modeli bulunmamakta, her firmanın içinde bulunduğu koşullara uyabilecek bir yönetim modeli geliştirmesi gerekmektedir. Yerel koşullar firma yapılarını ve stratejilerini etkileyebilmektedir. Sektördeki düşük rekabet o sektörü çekici kılmakta ancak yoğun rekabet ise firmaların rekabetçi yeteneklerini geliştirecek yenilik yaratma konusunda arayışlarda bulunmasına neden olacaktır. Dolasıyla işletme faaliyetlerinin gerçekleştirildiği sektörün özellikleri, rekabet durumu ve uygulanan stratejiler oldukça önemli olacaktır. Sektörde fiyatlandırma, yeni ürün ya da süreç oluşturma ya da teknoloji tabanlı ulusal rekabet gibi firmalar arası rekabet oluşacaktır (Aktan ve Vural, 2004: 61).

\subsection{5. Şans}

Ulusal avantajı belirleyen faktörler belirli endüstrilerde rekabeti şekillendirse de şans da bu hususta önemli bir rol oynar. Şans bir ülkedeki koşullarıyla az ilgisi olan ve genellikle firmaların ve devletin müdahalesi dişında gelişen olaylar olarak belirtilmektedir. Rekabet avantajını etkileyen önemli bazı şans faktörü örnekleri aşağıdaki gibidir (Porter, 1990: 124):

- Büyük teknolojik düzensizlikler

- Girdi maliyetlerindeki düzensizlikler (ör: petrol fiyatları)

- Dünya piyasalarındaki önemli değişiklikler ve kur değişimleri

- Ülke ya da dünya düzeyindeki talep dalgalanmaları

- Yabancı hükümetler arasındaki politik tartışmalar

- Savaşlar

Elmas Modelinde tanımlanan şans faktörü sektör ve/veya firmaların rekabetçiliğine etki edebilmektedir. Normal şartlarda edinilen bir rekabet avantajı aniden gelişen bir olay ile etkilenebilmekte ve bu avantaj başka bir sektöre ya da firmaya geçebilmektedir. 


\subsubsection{Devlet}

Elmas modelinde devlet faktörü rekabet gücü belirleyecek düzeyde etkisi olmasa da sektördeki fırsat ve tehditlere karşı alacağ1 kararlar ve uygulayacağ politikaların firmaların ve/veya sektörün rekabetçiliğine etki edeceği değerlendirilmektedir. Devletin uygulamalarının elmasın diğer dört faktörüne olumlu ya da olumsuz etkileri olabilir. Devlet hem sahip olunan kaynakların sürdürülebilirliği konusunda hem de ilgili sektörde düzenleyici rolü ile rekabetçilik ortamına katkıda bulunmaktadır. Devletin bu konudaki rolü düzenlemeler yapma ve işletmelerin verimliliklerini arttırabilecekleri teşviklerde bulunmak gibi uygulamaları bulunmaktadir (Porter, 1990: 127).

\subsection{Porter (1990)'ın Elmas Modeli İle Yapılan Bazı Çalışmalar}

Yapılan literatür taramasında belirli sektörlerin rekabetçilik analizinin yapılmasında Porter (1990)'ın Elmas Modelinin kullanıldığı birçok ulusal ve uluslararası çalışmaya rastlanmıştır.

Bulu, Eraslan ve Kaya (2006), çalışmalarında elmas modelini kullanarak Türk elektronik sektörünün rekabetçilik analizini yapmışlardır. Çalışma sonucunda bu sektörün rekabetçilik seviyesinin orta seviyede olduğu tespit edilmiştir. Elması oluşturan faktörlerin temel özellikleri çalışma sayesinde ortaya konmuş ve rekabetçilik seviyesinin arttırılabilmesine yönelik öneriler getirilmiştir.

Bulu, Eraslan ve Barca (2007), bir başka çalışmada ise elmas modelini kullanmak suretiyle Türk gıda sektörünün uluslararası rekabetçilik düzeyinin analizini yapmışlardır.

Eraslan, Bakan ve Kuyucu (2008), Türk tekstil ve hazır giyim sektörünün rekabet gücünün Porter'ın elmas modeli kullanılarak tespit edilmesi amaciyla yürüttükleri çalışmada rekabet gücünün ana etkenleri belirlenmiş ve bu endüstrinin rekabet gücünün yükseltilmesi için öneriler geliştirilmiştir.

Markus (2008), 500 firma üzerinde yürüttüğü çalışmasında Porter'ın elmas modelinin teorik çerçevesinde firma (mikro) düzeyinde rekabetçilik metodolojisi geliştirmeye çalışmıştır.

Gürpınar ve Sandıkçı (2008), Türkiye'de Porter'ın elmas modelinin cam, inşaat, deri ve giyim, otomotiv, çelik, mobilya, gıda, elektronik ve bilişim sektörlerinde uygulanarak rekabetçilik düzeylerinin belirlendiği farklı araştırmaların olduğunu bildirmiştir.

Bakan ve Doğan (2012)'in çalışmasında, Kahramanmaraş'in temel endüstrilerinin rekabetçiliği (tekstil, gıda, metal mutfak ekipmanları ve kuyumculuk) Porter'ın elmas modeli kullanılarak belirlenmeye çalışılmıştır.

Özer (2012)'nin çalışmasında Türk turizm endüstrisinin uluslararası rekabet gücünün değerlendirilmesi Porter'ın elmas modeli ile yapılmış ve Türkiye-İspanya endüstrileri bu çerçevede karşılaştırılmıştır. 
Nderitu (2012), yapmış olduğu çalışmasında Kenya'nın turizm sektörünün global pazardaki rekabetçiliğine etki eden faktörlerin Elmas Modelinin kullanılması ile belirlenmesini amaçlamıştır.

Pawar ve Veer (2013), Hindistan'ın perakendecilik sektöründeki doğrudan yabancı yatırımların stratejik rekabetçilik avantajının belirlenmesi için Michael Porter'ın elmas modelini kullanmışlardır.

Süygün (2013) tarafından yürütülen çalışmada Mersin yaş meyve sebze kümesinin başarılı olabilmesi için ortaya konması gerekenlerin belirlenmesi bir vaka analizi çerçevesinde incelenmiş ve bu kümenin rekabetçilik düzeyi de Porter'ın elmas modeli çerçevesinde araştırılmıştır. Çalışma sonucunda da faktör koşulları, ilgili ve destek endüstriler ve devlet faktörlerinin uluslararası rekabet gücü açısından dezavantajlı bir konumda olduğu bildirilmiştir.

Mboya ve Kazungu (2015), elmas modelini kullanarak Tanzanya'nın tekstil ve giyim endüstrisinin rekabet avantajlarının faktörlerinin belirlenmesi üzerine bir çalışma yürütmüşlerdir. Çalışma sonucunda en önemli iki faktörün talep koşulları ve ilgili ve destek endüstriler olduğunu bildirmişlerdir.

Riasi (2015), gölge bankacılık sisteminin neden global finans sisteminde gittikçe daha fazla rekabetçi hale geldiğinin ve nasıl kontrol edilebileceğinin tespit edilmesi amacıyla bir çalışma yürütmüştür. Bu amaçla Porter'ın elmas modelinin kullanılarak gölge bankacılığının rekabetçilik avantajları belirlenmiştir. Çalışma sonucunda faktör koşullarının, şansın ve devletin gölge bankacılık endüstrisinin rekabetçiliğine katkısının olmadığı, ancak diğer yandan ilgili ve destek endüstriler, firma stratejileri, yapı ve rekabet ile talep koşullarının ise bu endüstrinin rekabetçiliğine katkısının olduğu bildirilmiştir.

Rodrigues ve Kahn (2015), Güney Asya serbest ticaret bölgesi (SAFTA) ülkelerindeki giyim sektörünün rekabetçilik düzeyini Porter'ın elmas modelini kullanarak açıklamaya çalışmışlardır.

\section{YÖNTEM}

\subsection{Araştırmanın Amacı}

$\mathrm{Bu}$ çalışmanın amacı, Türkiye'nin su ürünleri yetiştiriciliği sektörünün uluslararası rekabetçilik düzeyinin Porter (1990)'ın Elmas modeli ile akademisyenlerin bakış açısından açıklanabilirlik seviyesini tespit etmektir. Böylelikle sektörün rekabetçilik düzeyinin ve rekabet yapısının temel özellikleri ortaya konması ve uluslararası pazar payının arttırılmasına yönelik stratejilerin geliştirilmesine katkı sağlanması hedeflenmektedir. Özellikle sektöre bilimsel araştırmalar ile katkı sağlayan ve teknik insan kaynağı yetiştiren üniversiteler ve araştırma enstitülerinde çalışan akademisyenlerin bakış açısıyla sektörün rekabetçilik düzeyi ortaya konulduğunda, rekabet avantajı elde edebilmek ve bu avantajı sürdürebilmek için sektörün sürdürülebilirliğine katkı sağlayacak stratejilerin geliştirilmesi için öneriler belirlenebilecektir. 


\subsection{Araştırmanın Modeli ve Veri Toplama Aracı}

Çalışma kapsamında Michael E. Porter (1990) tarafından geliştirilen ve uluslararası rekabet gücünü açıklayan modeller arasında açıklayıcılık seviyesinin en yüksek olduğu kabul edilen Elmas Modelinin teorik arka plan olarak kullanılması ve yukarıda özetlenen çalışmaların da incelenmesi sonucunda araştırmacı tarafından bir veri toplama aracı (anket) geliştirilmiştir. Bununla birlikte veri toplama aracının geliştirilmesi sürecinde bu konuda çalışan bazı akademisyenlerin de görüşleri alınmıştır.

Geliştirilen anket iki kısımdan oluşmaktadır. Anketin birinci kısmında çalışma kapsamına alınan üniversiteler-araştırma birimlerinde görev alan akademisyenlerin demografik değişkenlerinin belirlenebilmesi amacıyla oluşturulan sorular bulunmaktadır. Anketin ikinci kısmını ise rekabetçilik düzeyinin belirlenebilmesi için oluşturulmuş rekabetçilik düzeyi ölçeği oluşturmaktadır. Bu kısım elmasın köşelerini oluşturan faktörleri açıklayabilecek yapılandırılmış ifadeler ile oluşturulmuş ve söz konusu faktörlerin düzeyinin belirlenebilmesi amacıyla 5'li Likert ölçeği kullanılmıştır. Ankette ölçek ile ilgili sorular 1:Kesinlikle Katılmıyorum, 2:Katılmıyorum, 3:Kararsızım, 4:Katılıyorum, 5:Kesinlikle Katılıyorum şeklinde temsil edilmiştir. Anket geliştirildikten sonra bir pilot çalışma uygulanmış, yapılan güvenirlik analizinde Cronbach Alfa katsayısının 0,845 bulunmasıyla anketin yüksek güvenirlikte olduğu kabul edilerek anket sorularında herhangi bir değişiklik yapılmamıştır. Anketin geliştirilmesini takiben anket soruları elektronik ortama aktarılmış ve evrende yer alan araştırmaci/akademisyenlerin kişisel e-postalarına elektronik ortamda gönderilmesiyle veriler toplanmıştır.

\subsection{Evren ve Örneklem}

Araştırmanın evrenini Türkiye'de bulunan ve araştırma ve/veya eğitim öğretime devam eden balıkçılık ve su ürünleri ile ilgili Üniversiteler ve Araştırma Enstitülerinde görev yapan akademisyenler oluşturmaktadır. Evrene dahil edilen araştırma kuruluşları listesi ve anket gönderilen araştırmacı sayısı Tablo 1'de verilmiştir. 
Tablo 1. Anket Gönderilen Araştırma Birimleri ve Araştırmacı Sayısı

\begin{tabular}{|c|c|c|}
\hline & Araştırma Birimi Adı & $\begin{array}{l}\text { Araştırmacı } \\
\text { Sayıs1 }\end{array}$ \\
\hline 1 & $\begin{array}{l}\text { Ankara Üniversitesi Ziraat Fakültesi Su Ürünleri Mühendisliği } \\
\text { Bölümü }\end{array}$ & 14 \\
\hline 2 & Ege Üniversitesi Su Ürünleri Fakültesi & 96 \\
\hline 3 & Mersin Üniversitesi Su Ürünleri Fakültesi & 24 \\
\hline 4 & Muğla Sıtkı Koçman Üniversitesi Su Ürünleri Fakültesi & 34 \\
\hline 5 & Akdeniz Üniversitesi Su Ürünleri Fakültesi & 24 \\
\hline 6 & İzmir Katip Çelebi Üniversitesi Su Ürünleri Fakültesi & 17 \\
\hline 7 & Çukurova Üniversitesi Su Ürünleri Fakültesi & 49 \\
\hline 8 & Süleyman Demirel Üniversitesi Su Ürünleri Fakültesi & 23 \\
\hline 9 & Sinop Üniversitesi Su Ürünleri Fakültesi & 43 \\
\hline 10 & $\begin{array}{l}\text { İskenderun Teknik Üniversitesi Deniz Bilimleri ve Teknoloji Fakültesi } \\
\text { Su Ürünleri Mühendisliği Bölümü }\end{array}$ & 31 \\
\hline 11 & Atatürk Üniversitesi Su Ürünleri Fakültesi & 12 \\
\hline 12 & Recep Tayyip Erdoğan Üniversitesi Su Ürünleri Fakültesi & 36 \\
\hline 13 & Kastamonu Üniversitesi Su Ürünleri Fakültesi & 8 \\
\hline 14 & $\begin{array}{l}\text { Çanakkale Onsekiz Mart Üniversitesi Deniz Bilimleri ve Teknoloji } \\
\text { Fakültesi Su Ürünleri Mühendisliği Bölümü }\end{array}$ & 36 \\
\hline 15 & $\begin{array}{l}\text { Girne Üniversitesi Deniz Bilimleri Fakültesi Balıkçlık Teknolojisi } \\
\text { Mühendisliği Bölümü }\end{array}$ & 14 \\
\hline 16 & $\begin{array}{l}\text { Ordu Üniversitesi Fatsa Deniz Bilimleri Fakültesi Balıkçılık } \\
\text { Teknolojisi Mühendisliği Bölümü }\end{array}$ & 15 \\
\hline 17 & $\begin{array}{l}\text { Karadeniz Teknik Üniversitesi Sürmene Deniz Bilimleri Fakültesi } \\
\text { Balıkçlık Teknolojisi Mühendisliği }\end{array}$ & 6 \\
\hline 18 & $\begin{array}{l}\text { Fırat Üniversitesi Su Ürünleri Fakültesi Balıkçılık Teknolojisi } \\
\text { Mühendisliği Bölümü }\end{array}$ & 31 \\
\hline 19 & İstanbul Üniversitesi Su Bilimleri Fakültesi & 62 \\
\hline 20 & $\begin{array}{l}\text { Akdeniz Su Ürünleri Araştırma Üretim ve Eğitim Enstitüsü } \\
\text { Müdürlüğ̈u (Antalya) }\end{array}$ & 44 \\
\hline 21 & Su Ürünleri Merkez Araştırma Enstitüsü Müdürlüğü (Trabzon) & 47 \\
\hline 22 & Su Ürünleri Araştırma Enstitüsü Müdürlüğü (Eğridir-Isparta) & 23 \\
\hline \multirow[t]{2}{*}{23} & Su Ürünleri Araştırma Enstitüsü Müdürlüğü (Elazığ) & 39 \\
\hline & TOPLAM & 728 \\
\hline
\end{tabular}

Araştırmada basit tesadüfi örnekleme yönteminden yararlanılmıştır. Tablo 1'den görüldügü üzere, 575 adedi Üniversiteler, 153 adedi Gida Tarım ve Hayvancılık Bakanlığına bağlı araştırma enstitüleri olmak üzere toplam 728 kişiye anket, araştırmacının kişisel e-posta adresinden katılımcıların kişisel/kurumsal e-posta adreslerine 09 Ekim ile 06 Kasım 2017 tarihleri arasında elektronik ortamda gönderilmiştir. Buna göre elektronik olarak doldurulan anket sayısı 84 olmuş olup, çalışma bu anketlerden elde edilen veriler ile yürütülmüştür. Ankete katılım oranı $\%$ 11,54 olarak hesaplanmıştır. $\alpha=0,05$ anlamlılık düzeyinde, $\mathrm{d}= \pm 0,10$ örnekleme hatası 
ve \%95 güven düzeyinde ana kütle büyüklügü 750 olan bir evrenden 85 örnekleme yapılabilir (Yazıcıoğlu ve Erdoğan, 2014: 89). Buna göre çalışma sonucunda katılımcılar tarafından doldurulan anket sayısının $\alpha=0,05$ anlamlılık ve $\% 95$ güven düzeyinde, $\mathrm{d}= \pm$ 0,10 örnekleme hatasıyla ana kütleyi temsil ettiği anlaşılmıştır.

\subsection{Araştırmanın Hipotezleri}

Araştırmanın amacına göre hipotezler aşağıdaki şekilde oluşturulmuştur:

H1: Üniversite ve Araştırma Enstitüleri birimleri arasında sektörün gelecek beklentisi, kar marjı ve rekabet stratejisi için istatistiksel açıdan anlamlı bir fark vardır.

H2: Ana Bilim Dalları arasında sektörün gelecek beklentisi, kar marjı ve rekabet stratejisi için istatiksel açıdan anlamlı bir fark vardır.

H3: İş tecrübesi grupları arasında sektörün gelecek beklentisi, kar marjı ve rekabet stratejileri için istatistiksel açıdan anlamlı bir fark vardır

H4: Üniversite ve Araştırma Enstitüleri birimleri arasında rekabeti etkileyen kuvvetler için istatistiksel açıdan anlamlı bir fark vardır.

H5: Ana Bilim Dalları arasında rekabeti etkileyen kuvvetler için istatistiksel açıdan anlamlı bir fark vardır.

H6: İş tecrübesi grupları arasında rekabeti etkileyen kuvvetler için istatistiksel açıdan anlamlı bir fark vardır.

H7: Üniversite ve Araştırma Enstitüleri birimleri arasında elması oluşturan faktörler için istatistiksel açıdan anlamlı bir fark vardır.

H8: Ana Bilim Dalları arasında elması oluşturan faktörler için istatistiksel açıdan anlamlı bir fark vardır.

H9: İş tecrübesi grupları arasında elması oluşturan faktörler için istatistiksel açıdan anlamlı bir fark vardır.

\subsection{Verilerin Analizi}

Araştırma örnekleminden elde edilen veriler istatistiksel analize tabi tutulabilmeleri için SPSS 22 paket programa girilmiştir. Daha öncelikle verilerin güvenirlik analizi ve hangi istatistiksel metotların kullanılacağının tespit edilebilmesi için normallik testleri uygulanmıştır.

\subsection{1. Ölçeğin Güvenirlik Analizi}

Bir araştırmada elde edilen verilerin güvenirliliğinin belirlenmesi, ölçeğin iyi olduğunun anlaşılabilmesi için önemlidir. Cronbach alfa güvenilirlik katsayısı ölçek güvenilirliğinin saptanmasında yaygın olarak kullanılmaktadır. Kabul edilebilir alfa değerleri ile ilgili farklı yorumlamalar bulunmakla beraber, genel kanı ölçeğin güvenilir olduğunu söyleyebilmek için bu katsayının 0,70 ile 0,95 aralığı arasında olması gerektiğidir (Tavakol ve Dennink, 2011: 54). 
Araştırmacı tarafından hazırlanan ölçeğin güvenilirliğinin saptanması amacıyla hem boyutların hem de tüm ölçeğin Cronbach alfa katsayısı hesaplamaları yapılmıştır. Yapılan hesaplama sonuçları Tablo 2' te gösterilmiştir.

Tablo 2. Ölçeğin Güvenilirlik Analizi

\begin{tabular}{|c|c|c|}
\hline Boyut Adı & Soru Sayısı & Cronbach Alfa Katsayısı \\
\hline Faktör Koşulları & 7 & 0,54 \\
\hline Talep Koşulları & 7 & 0,69 \\
\hline İlgili Destek Endüstriler & 7 & 0,77 \\
\hline Firma Yapısı, Strateji ve Rekabet & 7 & 0,66 \\
\hline Devlet & 6 & 0,63 \\
\hline Şans & 3 & 0,32 \\
\hline ÖLÇEK & 37 & 0,84 \\
\hline
\end{tabular}

Ölçeğin güvenilirlik testi sonucunda elde edilen değerin 0,50 den daha az olması durumunda ölçeğin düşük güvenilirlikte, 0,50 ile 0,80 arasında olması durumunda ölçeğin orta seviyede güvenilirlikte ve 0,80 'den daha büyük olması durumunda ise ölçeğin yüksek güvenilirlikte olduğu belirtilmektedir (Salvucci vd, 1997:115). Tablo 4'ten görüldüğü üzere, boyutlar bazında bakıldığında Şans boyutları hariç diğer boyutların Cronbach alfa değerlerinin kabul edilebilir sınırlar içinde kaldığı görülmektedir. Şans boyutunun alfa katsayısı oldukça düşük çıkmıştır. Az sayıda soru olduğunda Cronbach alfa katsayısının düşük çıkabildiği belirtilmektedir (Tavakol ve Dennink, 2011:54). Bu boyutta sadece 3 soru bulunduğundan alfa katsayısının düşük çıtı̆̆ 1 düşünülmektedir.

Tüm ölçeğin Cronbach alfa güvenilirlik kat sayısı 0,84 olarak hesaplanmış olup, bu da ölçeğin yüksek seviyede güvenilir olduğunu göstermektedir.

Ölçek, Porter'ın Elmas Modelini oluşturan faktörler esas alınarak hazırlandığından faktör analizine tabi tutulmamıs, önermelerin o faktörü temsil ettiği kabul edilmiştir.

\section{BULGULAR}

\subsection{Tanımlayıcı İstatistikler}

Araştırma kapsamındaki katılımcların cinsiyet, yaş, eğitim durumu, tecrübe ve çalıştıkları pozisyonlara gibi demografik özelliklere ilişkin f değerleri ve \% karşılıkları Tablo 6'da gösterilmiştir. 
Tablo 6. Katılımcıların Demografik Özellikleri $(\mathrm{f}=84)$

\begin{tabular}{|c|c|c|c|c|c|c|c|}
\hline & Özellikler & $\mathrm{f}$ & $\%$ & \multicolumn{2}{|c|}{ Özellikler } & $f$ & $\%$ \\
\hline \multirow{2}{*}{ Cinsiyet } & Erkek & 65 & 77,38 & Lisansüstü & Var & 74 & 88,10 \\
\hline & Kadın & 19 & 22,62 & Derecesi $^{2}$ & Yok & 6 & 7,14 \\
\hline \multirow{3}{*}{ Yaş $^{2}$} & $20-30$ & 6 & 7,14 & \multirow{3}{*}{ Tecrübe $^{2}$} & $1-10$ yil & 18 & 21,43 \\
\hline & $31-40$ & 28 & 33,33 & & $11-20$ y1l & 30 & 35,71 \\
\hline & 41 ve üstü & 48 & 57,14 & & 21 yıl ve üstü & 32 & 38,09 \\
\hline \multirow{5}{*}{ Mezuniyet } & Su Ür. Müh. & 58 & 69,05 & \multirow[b]{2}{*}{ Birim } & Üniversite & 62 & 73,81 \\
\hline & Bal. Tek. Müh. & 6 & 7,14 & & Araştırma Enst. & 22 & 26,29 \\
\hline & Ziraat Müh. & 6 & 7,14 & \multirow{3}{*}{$\begin{array}{c}\text { Ana Bilim } \\
\text { Dalı }\end{array}$} & Su Ürünleri Yet. & 54 & 64,29 \\
\hline & Veteriner Hekim & 5 & 5,95 & & Temel Bilimler & 16 & 19,05 \\
\hline & Diğer ${ }^{3}$ & 9 & 10,72 & & Avl. İşl. Tekn. & 14 & 16,66 \\
\hline \multirow{7}{*}{ Unvan } & Prof. Dr. & 18 & 21,43 & \multirow{7}{*}{ İdari Görev } & Dekan & 3 & 3,57 \\
\hline & Doç. Dr. & 8 & 9,52 & & Dekan Yard. & 4 & 4,76 \\
\hline & Yard. Doç. Dr. & 14 & 16,66 & & ABD/Böl. Bşk & 16 & 19,05 \\
\hline & Dr. & 16 & 19,05 & & Enst. Müd. & 1 & 1,19 \\
\hline & Uzman & 10 & 11,91 & & Enst. Müd. Yrd. & 2 & 2,38 \\
\hline & Araştırma Görevlisi & 8 & 9,52 & & Koordinatör & 2 & 2,38 \\
\hline & Akademik Unvanı Yok & 10 & 11,91 & & İdari Görev Yok & 56 & 66,67 \\
\hline
\end{tabular}

Anketi dolduran araştırmacıların \% 77,38'i erkek, \% 22,62'si kadındır. Katılımcıların ortalama yaşı 42,84 ( \pm 0,905 S.H.) ve ortalama tecrübeleri ise 18,19 ( \pm 0,970 S.H.) yıldır. Anketi dolduranların \% 76,19'u su ürünleri mühendisi ve balıkçılık teknolojisi mühendisidir. Katılımcıların \% 88,10'unun lisansüstü derecesi mevcut olup, \% 66,66'sı ise doktora mezunudur. Ankete katılan araştırmaciların \% 33,33'ü çalıştıkları birimde yönetici olarak çalışmakta ve \% 64,29'u su ürünleri yetiştiriciliği anabilim dalında görev almaktadırlar.

\footnotetext{
${ }^{2}$ Bu sorular için cevap vermeyen katılımcılar bulunmaktadır.

${ }^{3}$ (Gıda Müh, Biyolog, Kimya Müh, Matematik $\ddot{O} \breve{g r}$. vb)
} 
Tablo 7. Katılımcıların Araştırma Birimlerine Göre Dağılımları (f=84)

\begin{tabular}{lcc}
\hline \multicolumn{1}{c}{ Araştırma Birimi Adı } & f & \% \\
\hline Ege Üniversitesi & 3 & 3,57 \\
Mersin Üniversitesi & 4 & 4,77 \\
Muğla Sıtkı Koçman Üniversitesi & 2 & 2,38 \\
Süleyman Demirel Üniversitesi & 2 & 2,38 \\
Sinop Üniversitesi & 5 & 5,95 \\
Firat Üniversitesi & 2 & 2,38 \\
İstanbul Üniversitesi & 4 & 4,77 \\
Recep Tayyip Erdoğan Üniversitesi & 2 & 2,38 \\
Çanakkale Onsekiz Mart Üniversitesi & 1 & 1,19 \\
Ordu Üniversitesi & 2 & 2,38 \\
Çukurova Üniversitesi & 1 & 1,19 \\
Kastamonu Üniversitesi & 5 & 5,95 \\
Akdeniz Su Ürünleri Araştırma Enstitüsü & 3 & 3,57 \\
Elazı̆̆ Su Ürünleri Araştırma Enstitüsü & 3 & 3,57 \\
Su Ürünleri Merkez Araştırma Enstitüsü (Trabzon) & 5 & 5,95 \\
Yanıt Yok & 40 & 47,62 \\
TOPLAM & $\mathbf{8 4}$ & $\mathbf{1 0 0 , 0 0}$ \\
\hline
\end{tabular}

Tablo 8'dan görüldüğü üzere ankete katılanların oranı araştırma kapsamına alınan üniversitelere ve araştırma birimlerine yayılım göstermektedir. Ankete katılan araştırmacıların \% 47,62' si ise hangi birimde çalıştığını belirtmek istememişlerdir.

Katılımclardan elde edilen verilere göre rekabete etki eden 5 kuvvete ait ortalamalar ve standart hataları Tablo 8'de verilmiştir.

Tablo 8. Rekabete Etki Eden Beş Kuvvete Ait Ortalama ve Standart Hatalar (f:83)

\begin{tabular}{lcc}
\hline \multicolumn{1}{c}{ Kuvvet } & Ort & S.H. \\
\hline Sektöre Yeni Giriş & 2,63 & 0,12 \\
Alıcıların Gücü & 3,17 & 0,11 \\
Tedarikçilerin Gücü & 3,33 & 0,11 \\
Firmalar Arası Rekabet & 3,64 & 0,12 \\
İkame Ürünlerin Etkisi & 3,57 & 0,14 \\
\hline
\end{tabular}

Tablo 8'den görüldüğü üzere, rekabeti etkileyen kuvvetlerin en önemlisi akademisyenlere Göre Firmalar Arası Rekabet olmuştur $(3,64 \pm 0,12)$. Bunu İkame Ürünlerin Etkisi takip etmiştir $(3,57 \pm 0,14)$. Sonrakiler ise sırasıyla Tedarikçilerin Gücü $(3,33 \pm 0,11)$, Alıcıların Gücü $(3,17 \pm 0,11)$ ve Sektöre Yeni Giriş $(2,63 \pm 0,12)$ takip etmiştir.

\subsection{Elmas Modeli}

Anketler yoluyla elde edilen birincil veriler, tek örneklem $t$ testi analizi yöntemiyle test değeri 3,67 olacak şekilde analiz edilmiş ve istatistiksel açıdan anlamlı olan önermelerin önem dereceleri ortalama değerlerine göre $1-2,33$ aralığ1 (-), 2,34 3,66 aralığ 1 (o) ve 3,67 - 5,00 aralığ1 (+) olacak şekilde elmasta yerlerine yerleştirilmiştir. Ayrıca elmasın her bir köşesini oluşturan boyutların ortalama değeri ve standart hatası 
da hesaplanarak ülkemizin su ürünleri yetiştiriciliği sektörünün rekabetçilik düzeyi üniversiteler/araştırma birimleri boyutunda tespit edilmeye çalışılmıştır.

Firma Stratejisi Yapı ve Rekabet

$(3,60 \pm 0,06)$

Şans $(3,61 \pm 0,09)$

o AR-GE'yi yakından takip $(3,01)$

o Teknoloji kullanımı $(3,15)$

+ Kurumsal yapı $(4,01)$

+ Firma büyüklükleri $(4,19)$

+ Firma stratejileri $(4,48)$

o Modern işletme yönetimi uyg. $(2,83)$

Faktör Koşulları $(3,79 \pm 0,05)$

o Hammadde temini $(2,60)$

+ Mühendis varlığ $1(4,38)$

+ Nitelikli insan kaynağ $(4,46)$

+ Doğal kaynaklar $(4,65)$

+ Bilimsel ve teknik altyap 14,19$)$

o Yeterli sermaye varlığ $1(2,70)$

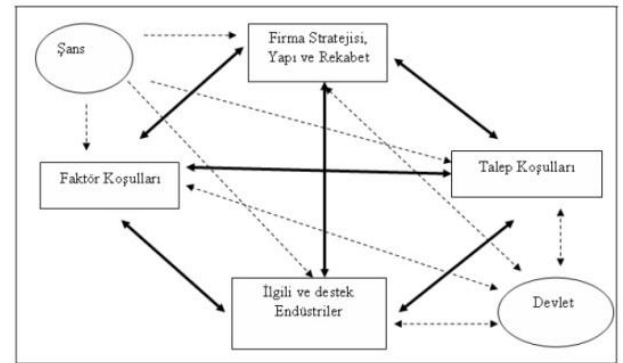

İlgili ve Destek Endüstriler $(2,78 \pm 0,07)$

o Balık yemi fab. varlığ $1(2,98)$

- Örgütlenme $(2,15)$

- Üniv-firmalar arası işbirliği $(2,13)$

- Bilgi akışı $(2,20)$

o Gelişmiş tedarikçi varlığ $(3,15)$

o İşleme tesisi varlığı $(2,80)$

+ Market ve AVM balık satı̧̧ yerleri $(4,05)$
Talep Koşulları $(3,13 \pm 0,06)$

o İç talebin düzeni $(2,54)$

- Tüketim miktarı $(1,83)$

o İç talebin büyümesi $(3,21)$

o Tük. alışkanlıkları değişimi $(3,43)$

o Diş talebin düzeni $(3,43)$

+ Diş talebin büyümesi $(3,96)$

\section{Devlet $(3,07 \pm 0,06)$}

o Üretim destekleri $(3,17)$

+ Yatırım destekleri $(4,17)$

- Bilgilendirme politikaları $(2,36)$

o Vergilendirme politikaları $(2,71)$

o Mevzuat uygulamaları $(2,49)$

Şekil 2. Üniversiteler/Araştırma Birimleri Boyutunda Türkiye Su Ürünleri Yetiştiriciliği Rekabet Düzeyi (Ort \pm S.H.)

Ankete katılan katılımcılardan elde edilen verilere göre oluşturulan elmas Şekil 2'de gösterilmiştir. Şekil 2'den görüleceği üzere, elmasın köşelerini oluşturan

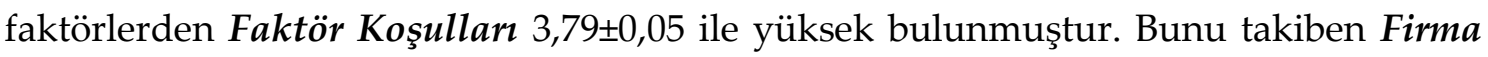

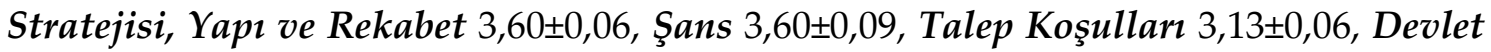
$3,06 \pm 0,06$ ve son olarak da Ilgili ve Destek Endüstriler 2,78 $\pm 0,07$ ile orta düzeyde bulunmuştur. Bu verilerden yola çıkarak Üniversiteler/Araştırma Birimleri boyutunda

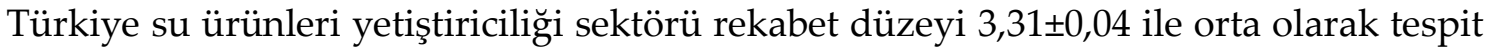
edilmiştir.

\subsection{Hipotez Testleri}

Bilimsel çalışmalarda verilerin özelliklerine göre parametrik ve parametrik olmayan analiz teknikleri kullanılmaktadır. Bu analiz tekniklerinin kullanılması da bazı varsayımlara dayanmaktadır. Özellikle t testi, tek yönlü ANOVA testi, korelasyon analizi gibi parametrik testlerin uygulanabilmesi ve sonuçların sağlıklı yorumlanabilmesi için verilerin normal dağılım göstermesi gerekmektedir (Yazıcı̆̆ğlu ve Erdoğan, 2014:245-246). Bu nedenle hipotez testlerinin analizine geçilmeden önce verilerin normallik varsayımları tespit edilmiştir. 
Tablo 3. Verilerin Normallik Varsayımı Testleri

\begin{tabular}{ccccc}
\hline Değişken Adı & $\begin{array}{c}\text { Çarpıklık } \\
\text { Katsayısı }\end{array}$ & S.H. & $\begin{array}{c}\text { Basıklık } \\
\text { Katsayısı }\end{array}$ & S.H. \\
\hline Faktör Koşulları & 0,47 & 0,26 & 0,34 & 0,52 \\
Talep Koşulları & $-0,09$ & 0,26 & $\mathbf{1 , 3 4}$ & 0,52 \\
IDE & 0,18 & 0,26 & 0,67 & 0,52 \\
FY, Str, Rek. & $-0,35$ & 0,26 & $-0,14$ & 0,52 \\
Devlet & 0,25 & 0,26 & 0,31 & 0,52 \\
Şans & $-0,24$ & 0,26 & $-0,35$ & 0,52 \\
\hline
\end{tabular}

Tablo 3'den görüldüğü üzere tüm değişkenlerin çarpıklık katsayılarının $-1<x<1$ aralığında kaldığı görülmektedir. Talep Koşulları değişkeni hariç tüm değişkenlerin de basıklık katsayılarının $-1<x<1$ aralığında kaldığı görülmektedir. Bu nedenle Talep Koşulları değişkeni hariç diğer tüm değişkenlerin normal dağılım gösterdiği anlaşılmıştır (Demir, Saatçioğlu ve İmrol, 2016:133-134). Bu değişken için bir de Kolmogorov-Simirnov ve Shapiro-Wilk hipotez testleri uygulanmış olup, hipotez test sonuçları ise Tablo 4'te verilmiştir.

Tablo 4. Verilerin Normallik Varsayımı Hipotez Testi

\begin{tabular}{ccccccc}
\hline \multirow{2}{*}{ Değişken Adı } & \multicolumn{3}{c}{ Kolmogorov-Smirnov } & \multicolumn{3}{c}{ Shapiro-Wilk } \\
& İst. & $\mathbf{d f}$ & $\mathbf{p}$ & İst. & $\mathbf{d f}$ & $\mathbf{P}$ \\
\hline Talep Koşulları & 0,10 & 84 & 0,04 & 0,98 & 84 & 0,15 \\
\hline
\end{tabular}

Kullanılan hipotez testinin gücü önemlilik seviyesine, örnek sayısına ve dağılımlara bağlı olarak değişiklik göstermekte olsa da, genel olarak Shapiro-Wilk testinin tüm dağılımlarda ve örneklem sayılarında en kuvvetli test olduğu bildirilmektedir (Razali ve Wah, 2011: 32). Bu nedene Shapiro-Wilk hipotez testi sonuçlarına göre değerlendirme yapılmış olup, $p$ değerlerinin $p>0,05$ olduğu görüldügünden Talep Koşullan değişkeninin de normal dağılım sergilediği kabul edilmiştir.

$\mathrm{Bu}$ sonuçlara göre elmas modelinin köşelerini oluşturan tüm değişkenlere ait verilerin normal dağılım gösterdiği söylenebilir.

Analize tabi tutulacak rekabeti etkileyen kuvvetlere ait çarpıklık ve basıklık katsayıları Tablo 5'de verilmiştir. 
Tablo 5. Rekabeti Etkileyen Kuvvetlere Ait Verilerin Normallik Varsayımı Testleri

\begin{tabular}{ccccc}
\hline Değişken Adı & $\begin{array}{c}\text { Çarpıklık } \\
\text { Katsayısı }\end{array}$ & S.H. & $\begin{array}{c}\text { Basıklık } \\
\text { Katsayısı }\end{array}$ & S.H. \\
\hline Sektöre Yeni Giriş & 0,35 & 0,26 & $-0,33$ & 0,52 \\
Alıcıların Gücü & 0,12 & 0,26 & $-0,25$ & 0,52 \\
Tedarikçilerin Gücü & $-0,22$ & 0,26 & $-0,32$ & 0,52 \\
Firmalar Arası Rekabet & $-0,84$ & 0,26 & 0,11 & 0,52 \\
İkame Ürünlerin Etkisi & $-0,64$ & 0,26 & $-0,57$ & 0,52 \\
\hline
\end{tabular}

Tablo 5'ten görüldügü üzere, rekabeti etkileyen tüm kuvvetlerin çarpıklık ve basıklık katsayılarının $1<x<1$ aralığında kaldığı görülmektedir. Bu nedenle rekabeti etkileyen faktörlere ait verilerin de normal dağılım gösterdiği anlaşılmıştır (Demir, Saatçioğlu ve İmrol, 2016:133-134).

$\mathrm{Bu}$ hesaplamalar neticesinde gruplar arasında fark olup olmadığının anlaşılması amacıyla normal dağılım sergileyen değişkenler için parametrik testlerden t-test ve ANOVA, normal dağılım sergilemeyen değişkenler için parametrik olmayan testlerden Mann-Whitney U ve Kruzkal Wallis testleri uygulanmıştır. Değişkenler arası ilişkileri tespit edebilmek amacıyla da korelasyon analizinden faydalanılmıştır. ANOVA testi uygulanırken varyansların homojenliği Levene testi ile test edilmiş ve bu test sonucunda varyans ortalamaları eşit olan değişkenler için ANOVA-Schefee, eşit olmayanlar için ise ANOVA-Tamhane testi uygulanmıştır.

Genel olarak parametrik olmayan testlerle normal dişı dağılım gösteren sayısal veriler analiz edilebilirken, parametrik testlerde ise normal dağılım gösteren verilerin analizi yapılabilmektedir. Ayrıca normal dağılım gösteren verilere parametrik olmayan testlerin uygulanması mümkün iken, normal dağılım göstermeyen veriler için parametrik testlerin uygulanması hatalı kabul edilmektedir (Altıntaş ve Karakaya, 2017:193).

Kar Marjı ve Rekabet stratejisi değişkenleri için birimler arasında farklılık olup olmadığının tespit edilmesi amacıyla bağımsız örneklem t-testi uygulanmıştır. Gelecek Beklentisi değişkeninin birimler arasında farklılık gösterip göstermediğinin tespit edilmesi amacıyla Mann-Whitney U testi uygulanmıştır. İstatistiksel analiz sonuçları Tablo 9 ve Tablo 10'da gösterilmiştir.

Tablo 9. Birimler ile Kar Marjı ve Rekabet Stratejisi t-testi Sonuçları

\begin{tabular}{|c|c|c|c|c|c|}
\hline \multirow[t]{2}{*}{ Değişken } & \multicolumn{2}{|c|}{$\begin{array}{c}\text { Lavene Varyansların Eşitliği } \\
\text { Testi }\end{array}$} & \multicolumn{3}{|c|}{ t-testi sonuçları } \\
\hline & $\mathbf{F}$ & $\mathbf{p}$ & $\mathbf{t}$ & S.D. & $\mathbf{p}$ \\
\hline Kar Marjı & 0,73 & 0,40 & 0,69 & 82 & 0,49 \\
\hline Rekabet Stratejisi & 4,77 & 0,03 & 0,47 & 28,81 & 0,65 \\
\hline
\end{tabular}

Yapılan t-testi sonuçlarına göre birimler arasında Kar Marjı ve Rekabet Stratejileri değişkenleri için istatistiksel açıdan anlamlı bir fark tespit edilememiştir $(\mathrm{p}>0,05)$. 
G. Dalkıran, F. Z. Tan / Karabük Üniversitesi Sosyal Bilimler Enstitüsü Dergisi, 2018, 8 (2),485-514

Tablo 10. Birimler (B) ile Gelecek Beklentisi (GB) Mann-Whitney U Testi Sonuçları

\begin{tabular}{cccccc}
\hline Değişken & $\mathbf{N}$ & Test İstatistiği & Standart Hata & $\begin{array}{c}\text { Standartlaştırılmış } \\
\text { Test İstatistiği }\end{array}$ & $\mathbf{p}$ \\
\hline $\mathrm{B}-\mathrm{GB}$ & 84 & 553 & 59,71 & $-2,16$ & $\mathbf{0 , 0 3}$ \\
\hline
\end{tabular}

Ancak yapılan Mann-Whitney $U$ testi sonuçlarına göre birimler arasında Gelecek Beklentisi değişkenleri için istatistiksel açıdan anlamlı bir fark tespit edilmiştir $(\mathrm{p}<0,05)$.

Tablo 11. Birim-Gelecek Çaprazlama Tablosu

\begin{tabular}{ccccccccccc}
\hline & \multicolumn{1}{c}{ Gelecek } \\
\cline { 3 - 10 } & & \multicolumn{2}{c}{ Düşer } & Aynı Kalır & Artar & \multicolumn{2}{c}{ Toplam } \\
\cline { 3 - 10 } & $\mathbf{n}$ & $\%$ & $\mathbf{n}$ & $\%$ & $\mathbf{n}$ & $\mathbf{\%}$ & $\mathbf{n}$ & $\%$ \\
\hline \multirow{2}{*}{ Birim } & Üniversite & 0 & 0,00 & 6 & 9,68 & 56 & 90,32 & 62 & 100 \\
& Araştırma Enstitüsü & 3 & 13,64 & 3 & 13,64 & 16 & 72,72 & 22 & 100 \\
& Toplam & 3 & 3,57 & 9 & 10,71 & 72 & 85,72 & 84 & 100 \\
\hline
\end{tabular}

$\mathrm{Bu}$ sonuçlara göre $\mathbf{H 1}$ hipotezi Kar Marjı ve Rekabet Stratejileri için reddedilmiş, Gelecek Beklentisi için ise kabul edilmiştir.

Kar Marjı ve Rekabet Stratejisi değişkenleri için ana bilim dalları arasında farklılık olup olmadığının tespit edilmesi amacıyla tek yön ANOVA testi uygulanmıştır. Analiz uygulanmadan önce yapılan Levene testi sonucunda varyansların homojen dağıldığı $(p>0,05)$ görülmüş olup gruplar arası farklılığın olup olmadığının anlaşılabilmesi için ANOVA-Schefee testi kullanılmıştır. İstatiksel analiz sonuçları Tablo 12 ve Tablo 13' de gösterilmiştir.

Tablo 12. Kar Marj1 - Ana Bilim Dalları ANOVA testi sonuçları

\begin{tabular}{cccccccccc}
\hline \multirow{2}{*}{ Değişkenler ve Gruplar } & \multicolumn{3}{c}{ Düşer } & \multicolumn{2}{c}{ Aynı Kalır } & \multicolumn{2}{c}{ Artar } & \multicolumn{2}{c}{ Toplam } \\
\cline { 2 - 10 } & $\mathrm{n}$ & $\%$ & $\mathrm{n}$ & $\%$ & $\mathrm{n}$ & $\%$ & $\mathrm{n}$ & $\%$ \\
\hline \multirow{3}{*}{ Kar Marjı } & Su Ür. Yet. ${ }^{a}$ & 14 & 25,93 & 32 & 59,26 & 8 & 14,81 & 54 & 100 \\
& Av. İs.s. Tek. $^{a}$ & 0 & 0,00 & 14 & 87,50 & 2 & 12,50 & 16 & 100 \\
& Tem. Bil. $^{a}$ & 4 & 28,57 & 7 & 50,00 & 3 & 21,43 & 14 & 100 \\
& Toplam $^{*}$ & 18 & 21,43 & 53 & 63,09 & 13 & 15,48 & 84 & 100 \\
\hline
\end{tabular}

Tablo 13. Rekabet Stratejisi - Ana Bilim Dalları ANOVA testi sonuçları

\begin{tabular}{|c|c|c|c|c|c|c|c|c|c|}
\hline \multicolumn{2}{|c|}{ Değişkenler ve Gruplar } & \multicolumn{2}{|c|}{$\begin{array}{l}\text { Maliyet } \\
\text { Liderliği }\end{array}$} & \multicolumn{2}{|c|}{$\begin{array}{c}\text { Ürün } \\
\text { Farklılaştırma }\end{array}$} & \multicolumn{2}{|c|}{ Odaklanma } & \multicolumn{2}{|c|}{ Toplam } \\
\hline & & $\mathbf{n}$ & $\%$ & $\mathbf{n}$ & $\%$ & $\mathbf{n}$ & $\%$ & $\mathbf{n}$ & $\%$ \\
\hline \multirow{4}{*}{$\begin{array}{l}\text { Rekabet } \\
\text { Stratejisi }\end{array}$} & Su Ür. Yet. ${ }^{a}$ & 8 & 14,81 & 38 & 70,38 & 8 & 14,81 & 54 & 100 \\
\hline & Av. İş. Tek. ${ }^{a}$ & 2 & 12,50 & 10 & 62,50 & 4 & 25,00 & 16 & 100 \\
\hline & Tem. Bil. ${ }^{a}$ & 3 & 21,43 & 9 & 64,29 & 2 & 14,28 & 14 & 100 \\
\hline & Toplam & 13 & 15,48 & 57 & 67,86 & 14 & 16,66 & 84 & 100 \\
\hline
\end{tabular}

Aynı sütunda farklı üst karakterlerle ifade edilen gruplar istatistiksel olarak birbirinden farklıdır $(p<0,05)$ 
Yapılan ANOVA testi sonuçlarına göre ana bilim dalları arasında Kar Marjı ve Rekabet Stratejisi için istatistiksel açıdan anlamlı bir fark tespit edilememiştir $(p>0,05)$.

Gelecek Beklentisi değişkeninin ana bilim dalları arasında farklılık gösterip göstermediğinin tespit edilmesi amacıyla Kruzkal-Wallis testi uygulanmıştır. İstatistiksel analiz sonuçları Tablo 14'de gösterilmiştir.

Tablo 14. Gelecek Beklentisi - Ana Bilim Dalları Kruzkal-Wallis testi sonuçları

\begin{tabular}{|c|c|c|c|c|c|c|c|c|c|}
\hline \multirow{2}{*}{\multicolumn{2}{|c|}{ Değişkenler ve Gruplar }} & \multicolumn{2}{|c|}{ Düşer } & \multicolumn{2}{|c|}{ Aynı Kalır } & \multicolumn{2}{|c|}{ Artar } & \multicolumn{2}{|c|}{ Toplam } \\
\hline & & $\mathrm{n}$ & $\%$ & $\mathrm{n}$ & $\%$ & $\mathrm{n}$ & $\%$ & $\mathrm{n}$ & $\%$ \\
\hline \multirow{4}{*}{$\begin{array}{l}\text { Gelecek } \\
\text { Beklentisi }\end{array}$} & Su Ür. Yet. ${ }^{a}$ & 1 & 1,85 & 3 & 5,55 & 50 & 92,60 & 54 & 100 \\
\hline & Av. İş. Tek. ${ }^{a, b}$ & 0 & 0,00 & 3 & 18,75 & 13 & 81,25 & 16 & 100 \\
\hline & Tem. Bil.b & 2 & 14,28 & 3 & 21,43 & 9 & 64,29 & 14 & 100 \\
\hline & Toplam & 3 & 3,57 & 9 & 10,72 & 72 & 85,71 & 84 & 100 \\
\hline
\end{tabular}

Aynı sütunda farklı üst karakterlerle ifade edilen gruplar istatistiksel olarak birbirinden farklıdır $(p<0,05)$

Tablo 14'ten anlaşılacağı üzere ana bilim dalları arasında su ürünleri sektörünün gelecek beklentisi değişkeni için istatistiksel açıdan anlamlı bir fark tespit edilmiştir $(p=0,020, p<0,05)$. SÜY ile AİT ana bilim dalları ve TB ile AİT ana bilim dalları istatistiksel olarak birbirine benzer iken, TB ana bilim dalının istatistiksel açıdan SÜY ana bilim dalından farklı olduğu tespit edilmiştir.

$\mathrm{Bu}$ sonuçlara göre $\boldsymbol{H} \mathbf{2}$ hipotezi Kar Marjı ve Rekabet Stratejileri için reddedilmiş, Gelecek Beklentisi için ise kabul edilmiştir.

Kar Marjı ve Rekabet Stratejisi değişkenleri için tecrübe grupları arasında farklılık olup olmadığının tespit edilmesi amacıyla tek yön ANOVA testi uygulanmıştır. Analiz uygulanmadan önce yapılan Levene testi sonucunda varyansların homojen dağıldığı $(p>0,05)$ görülmüss olup gruplar arası farklılı̆̆ın olup olmadığının anlaşılabilmesi için ANOVA-Shefee testi kullanılmıştır. İstatiksel analiz sonuçları Tablo 15'te gösterilmiştir. 
Tablo 15. Kar Marjı ve Rekabet Stratejisi - Tecrübe Grupları ANOVA testi sonuçları

\begin{tabular}{|c|c|c|c|c|c|c|c|c|c|}
\hline \multirow{2}{*}{\multicolumn{2}{|c|}{ Değişkenler ve Gruplar }} & \multicolumn{2}{|c|}{ Düşer } & \multicolumn{2}{|c|}{ Aynı Kalır } & \multicolumn{2}{|c|}{ Artar } & \multicolumn{2}{|c|}{ Toplam } \\
\hline & & $\mathrm{n}$ & $\%$ & $\mathrm{n}$ & $\%$ & $\mathrm{n}$ & $\%$ & $\mathrm{n}$ & $\%$ \\
\hline \multirow{4}{*}{ Kar Marj1 } & $1-10 \mathrm{yll}^{\mathrm{a}}$ & 5 & 27,77 & 10 & 55,56 & 3 & 16,67 & 18 & 100 \\
\hline & $11-20 y_{1} 1^{a}$ & 6 & 20,00 & 19 & 62,34 & 5 & 16,67 & 30 & 100 \\
\hline & 21 yıl ve üstüa & 7 & 21,87 & 20 & 62,50 & 5 & 16,63 & 32 & 100 \\
\hline & Toplam & 18 & 22,50 & 49 & 61,25 & 13 & 16,25 & 80 & 100 \\
\hline \multirow{2}{*}{\multicolumn{2}{|c|}{ Değişkenler ve Gruplar }} & \multicolumn{2}{|c|}{$\begin{array}{l}\text { Maliyet } \\
\text { Liderliği }\end{array}$} & \multicolumn{2}{|c|}{$\begin{array}{c}\text { Ürün } \\
\text { Farklılaştırma }\end{array}$} & \multicolumn{2}{|c|}{ Odaklanma } & \multicolumn{2}{|c|}{ Toplam } \\
\hline & & $\mathbf{n}$ & $\%$ & $\mathbf{n}$ & $\%$ & $\mathbf{n}$ & $\%$ & $\mathbf{n}$ & $\%$ \\
\hline \multirow{4}{*}{$\begin{array}{l}\text { Rekabet } \\
\text { Stratejisi }\end{array}$} & $1-10 \mathrm{y}^{\mathrm{a}} \mathrm{a}^{\mathrm{a}}$ & 2 & 11,11 & 10 & 55,56 & 6 & 33,33 & 18 & 100 \\
\hline & $11-20 y_{1}{ }^{a}$ & 6 & 20,00 & 23 & 76,67 & 1 & 3,33 & 30 & 100 \\
\hline & 21 yıl ve üstü ${ }^{a}$ & 4 & 12,50 & 21 & 65,62 & 7 & 21,88 & 32 & 100 \\
\hline & Toplam & 12 & 15,00 & 54 & 67,50 & 14 & 17,50 & 80 & 100 \\
\hline
\end{tabular}

Yapılan ANOVA testi sonuçlarına göre tecrübe grupları arasında Kar Marjı ve Rekabet Stratejisi için istatistiksel açıdan anlamlı bir fark tespit edilememiştir $(p>0,05)$.

Gelecek Beklentisi değişkeninin tecrübe grupları arasında farklılık gösterip göstermediğinin tespit edilmesi amacıyla Kruzkal-Wallis testi uygulanmıştır. İstatistiksel analiz sonuçları Tablo 16' da gösterilmiştir.

Tablo 16. Gelecek Beklentisi-Tecrübe Grupları Kruzkal-Wallis testi sonuçları

\begin{tabular}{lccccccccc}
\hline \multirow{2}{*}{ Değişkenler ve Gruplar } & \multicolumn{3}{c}{ Düşer } & \multicolumn{3}{c}{ Aynı Kalır } & \multicolumn{2}{c}{ Artar } & \multicolumn{2}{c}{ Toplam } \\
\cline { 2 - 10 } & $\mathrm{n}$ & $\%$ & $\mathrm{n}$ & $\%$ & $\mathrm{n}$ & $\%$ & $\mathrm{n}$ & $\%$ \\
\hline \multirow{3}{*}{ Gelecek } & $1-10 \mathrm{yl}^{\mathrm{a}}$ & 1 & 5,55 & 3 & 16,67 & 14 & 77,78 & 18 & 100 \\
Beklentisi & $11-20 \mathrm{yll}^{\mathrm{a}}$ & 2 & 6,67 & 3 & 10,00 & 25 & 83,33 & 30 & 100 \\
& 21 yıl ve üstü $^{\mathrm{a}}$ & 0 & 0,00 & 2 & 6,25 & 30 & 93,75 & 32 & 100 \\
& Toplam $^{2}$ & 3 & 3,75 & 8 & 10,00 & 69 & 86,25 & 80 & 100 \\
\hline
\end{tabular}

Aynı sütunda farklı üst karakterlerle ifade edilen gruplar istatistiksel olarak birbirinden farklıdır $(p<0,05)$

Tablo 16'dan anlaşılacağı üzere tecrübe grupları arasında Gelecek Beklentisi değişkeni için istatistiksel açıdan anlamlı bir fark tespit edilememiştir ( $p=0,235, p>0,05)$. Bu sonuçlara göre $\mathbf{H} 3$ hipotezi reddedilmiştir.

Rekabeti etkileyen beş kuvvete ait verilerin birimler arasında farklılık gösterip göstermediğinin tespit edilmesi amacıyla bağımsız örneklem t-testi analizi yapılmıştır. Test sonuçları Tablo 17' da gösterilmiştir. 
Tablo 17. Rekabet Güçleri - Birimler t-testi Sonuçları

\begin{tabular}{cccccc}
\hline \multirow{2}{*}{ Değişken } & \multicolumn{2}{c}{ Lavene Varyansların Eşitliği } & \multicolumn{3}{c}{ t-testi sonuçları } \\
& F & $\mathbf{p}$ & $\mathbf{t}$ & S.D. & $\mathbf{p}$ \\
\hline Sektöre yeni giriş & 1,79 & 0,19 & 0,17 & 81 & 0,86 \\
Alıcıların gücü & 0,04 & 0,83 & 0,94 & 81 & 0,35 \\
Tedarikçilerin gücü & 1,36 & 0,25 & 0,52 & 81 & 0,61 \\
Firmalar arası rekabet & 0,66 & 0,42 & 1,16 & 82 & 0,25 \\
İkame ürün etkisi & 2,33 & 0,13 & 1,65 & 81 & 0,10 \\
\hline
\end{tabular}

Tablo 17 'dan anlaşıldığ 1 üzere üniversiteler ve araştırma birimleri ile rekabeti oluşturan kuvvetler arasında istatistiksel açıdan önemli bir fark tespit edilememiştir ( $p>0,05)$. Bu sonuçlara göre $\boldsymbol{H} 4$ hipotezi reddedilmiştir.

Rekabeti etkileyen beş kuvvete ait verilerin ana bilim dalları arasında farklılık gösterip göstermediğinin tespit edilmesi amaciyla tek yönlü ANOVA testi uygulanmıştır. Analiz uygulanmadan önce yapılan Levene testi sonucunda Sektöre Yeni Giriş değişkeninin varyansının homojen dağılmadı̆̆ $(\mathrm{p}<0,05)$, diğer değişkenlerin ise homojen dağıldığı $(\mathrm{p}>0,05)$ görülmüştür. Bu nedenle Sektöre Yeni Giriş değişkeni için ANOVA-Tamhane, diğer değişkenler için ANOVA-Schefee testi kullanılmıştır. Test sonuçları Tablo 18' de gösterilmiştir.

Tablo 18. Rekabet Güçleri-Ana Bilim Dalları ANOVA testi Sonuçları

\begin{tabular}{|c|c|c|c|c|c|c|c|}
\hline \multicolumn{2}{|c|}{ Değişkenler ve Gruplar } & \multirow{2}{*}{$\frac{\text { Ort }}{2,68}$} & \multirow{2}{*}{$\begin{array}{r}\text { S.H. } \\
0,17\end{array}$} & \multicolumn{2}{|c|}{ Değişkenler ve Gruplar } & \multirow{2}{*}{$\frac{\text { Ort }}{3,25}$} & \multirow{2}{*}{$\frac{\text { S.H. }}{0,13}$} \\
\hline \multirow{3}{*}{$\begin{array}{l}\text { Sektöre Yeni } \\
\text { Giriş }\end{array}$} & Su Ür. Yet. ${ }^{a}$ & & & \multirow{3}{*}{ Alıcıların Gücü } & Su Ür. Yet. ${ }^{a}$ & & \\
\hline & Av. İss. Tek. ${ }^{a}$ & 2,63 & 0,13 & & Av. İş. Tek. & 3,31 & 0,27 \\
\hline & Tem. Bil. ${ }^{\mathrm{a}}$ & 2,43 & 0,31 & & Tem. Bil. $^{\mathrm{a}}$ & 2,71 & 0,24 \\
\hline \multirow{3}{*}{$\begin{array}{l}\text { Tedarikçilerin } \\
\text { Gücü }\end{array}$} & Su Ür. Yet. ${ }^{a}$ & 3,28 & 0,14 & \multirow{3}{*}{$\begin{array}{c}\text { Firmalar Arası } \\
\text { Rekabet }\end{array}$} & Su Ür. Yet. ${ }^{a}$ & 3,60 & 0,15 \\
\hline & Av. İş. Tek. ${ }^{a}$ & 3,56 & 0,22 & & Av. İş. Tek.a & 3,88 & 0,22 \\
\hline & Tem. Bil. ${ }^{\mathrm{a}}$ & 3,21 & 0,32 & & Tem. Bil. ${ }^{\mathrm{a}}$ & 3,43 & 0,34 \\
\hline \multirow{3}{*}{$\begin{array}{l}\text { İkame ürün } \\
\text { etkisi }\end{array}$} & Su Ür. Yet. ${ }^{a}$ & 3,62 & 0,16 & & & & \\
\hline & Av. İş. Tek. ${ }^{a}$ & 3,25 & 0,35 & & & & \\
\hline & Tem. Bil. ${ }^{\mathrm{a}}$ & 3,71 & 0,42 & & & & \\
\hline
\end{tabular}

Aynı sütunda farklı üst karakterlerle ifade edilen gruplar istatistiksel olarak birbirinden farklıdır $(p<0,05)$

Tablo 18'den anlaşıldığı üzere Ana Bilim Dalları ile rekabeti oluşturan kuvvetler arasında istatistiksel açıdan önemli bir fark tespit edilememiştir $(p>0,05)$. Bu sonuçlara göre $\mathbf{H} 5$ hipotezi reddedilmiştir.

Rekabeti etkileyen beş kuvvete ait verilerin yaş grupları arasında farklılık gösterip göstermediğinin tespit edilmesi amaciyla tek yönlü ANOVA testi uygulanmıştır. Analiz uygulanmadan önce yapılan Levene testi sonucunda Sektöre Yeni Giriş ve İkame Ürün Etkisi değişkenleri varyanslarının homojen dağılmadığı 
$(\mathrm{p}<0,05)$, diğer değişkenlerin ise homojen dağıldığı $(\mathrm{p}>0,05)$ görülmüştür. Bu nedenle Sektöre Yeni Giriş ve İkame Ürün Etkisi değişkeni için ANOVA-Tamhane, diğer değişkenler için ANOVA-Schefee testi kullanılmıştır. Test sonuçları Tablo 19'da gösterilmiştir.

Tablo 19. Rekabet Güçleri - Tecrübe Grupları ANOVA testi Sonuçları

\begin{tabular}{|c|c|c|c|c|c|c|c|}
\hline \multicolumn{2}{|c|}{ Değişkenler ve Gruplar } & \multirow{2}{*}{$\frac{\text { Ort }}{2,39}$} & \multirow{2}{*}{$\frac{\text { S.H. }}{0,20}$} & \multicolumn{2}{|c|}{ Değişkenler ve Gruplar } & \multirow{2}{*}{$\frac{\text { Ort }}{3,06}$} & \multirow{2}{*}{$\frac{\text { S.H. }}{0,22}$} \\
\hline \multirow{3}{*}{$\begin{array}{l}\text { Sektöre Yeni } \\
\text { Giriş }\end{array}$} & $1-10 \mathrm{y}_{1} \mathrm{a}^{\mathrm{a}}$ & & & \multirow{3}{*}{ Alıcıların Gücü } & $1-10 \mathrm{yll}^{\mathrm{a}}$ & & \\
\hline & $11-20 \mathrm{y} \mathrm{l}^{\mathrm{a}}$ & 2,59 & 0,19 & & $11-20 y_{1}{ }^{a}$ & 3,31 & 0,21 \\
\hline & 21 yıl ve üstü ${ }^{a}$ & 2,75 & 0,24 & & 21 yıl ve üstü ${ }^{a}$ & 3,09 & 0,16 \\
\hline \multirow{3}{*}{$\begin{array}{l}\text { Tedarikçilerin } \\
\text { Gücü }\end{array}$} & $1-10 \mathrm{yll}^{\mathrm{a}}$ & 2,83 & 0,26 & \multirow{3}{*}{$\begin{array}{c}\text { Firmalar Aras } \\
\text { Rekabet }\end{array}$} & $1-10 \mathrm{y}_{1} \mathrm{a}^{\mathrm{a}}$ & 3,33 & 0,21 \\
\hline & $11-20 \mathrm{yll}^{b}$ & 3,97 & 0,17 & & $11-20 \mathrm{y}^{1} \mathrm{a}^{\mathrm{a}}$ & 3,52 & 0,23 \\
\hline & 21 yıl ve üstü ${ }^{a}$ & 3,00 & 0,15 & & 21 yıl ve üstü ${ }^{a}$ & 3,87 & 0,19 \\
\hline \multirow{3}{*}{$\begin{array}{l}\text { İkame ürün } \\
\text { etkisi }\end{array}$} & $1-10 y_{1} 1^{a}$ & 3,17 & 0,28 & & & & \\
\hline & $11-20 \mathrm{yll}^{\mathrm{a}, \mathrm{b}}$ & 3,31 & 0,28 & & & & \\
\hline & 21 yıl ve üstü ${ }^{b}$ & 4,03 & 0,18 & & & & \\
\hline
\end{tabular}

Aynı sütunda farklı üst karakterlerle ifade edilen gruplar istatistiksel olarak birbirinden farklıdır $(p<0,05)$

Tablo 18'den anlaşıldığı üzere yaş grupları ile rekabeti oluşturan kuvvetlerden "Sektöre Yeni Giriş, Alıcıların Gücü ve Firmalar Arası Rekabet" güçleri arasında istatistiksel açıdan önemli bir fark tespit edilememişken ( $p>0,05)$, “Tedarikçilerin Gücü ve İkame Ürün Etkisi" için ise gruplar arasında istatistiksel açıdan anlamlı bir fark bulunmuştur $(p<0,05)$. Tedarikçilerin gücü değişkeni için 11-20 y1l tecrübeye sahip olanlar diğer iki gruptan önemli derecede farklılaşmışken, İkame Ürün Etkisi değişkeni için 1-10 yıl tecrübeye sahip olanlar ile 21 yıl ve üstü tecrübeye sahip olanlar arasında istatistiksel açıdan anlamlı bir fark tespit edilmiştir.

Bu sonuçlara göre $\mathbf{H 6}$ hipotezi Sektöre Yeni Giriş, Alıcıların Gücü ve Firmalar Arası Rekabet güçleri için reddedilmiş, Tedarikçilerin Gücü ve İkame Ürün Etkisi güçleri için ise kabul edilmiştir.

Elması oluşturan faktörlerin birimler arasında farklılık gösterip göstermediğinin tespit edilmesi amacıyla bağımsız örneklem t-testi analizi yapılmıştır. Test sonuçları Tablo 20' de gösterilmiştir. 
Tablo 20. Birim ile Elmas Faktörleri t-testi Sonuçları

\begin{tabular}{|c|c|c|c|c|c|}
\hline \multirow[t]{2}{*}{ Değişken } & \multicolumn{2}{|c|}{$\begin{array}{l}\text { Lavene Varyansların } \\
\text { Eşitliği Testi }\end{array}$} & \multicolumn{3}{|c|}{ t-testi sonuçları } \\
\hline & $\mathbf{F}$ & $\mathrm{p}$ & $\mathbf{t}$ & S.D. & p \\
\hline Faktör Koşulları & 0,17 & 0,68 & 1,43 & 82 & 0,16 \\
\hline Talep Koşulları & 1,20 & 0,28 & 2,11 & 82 & 0,04 \\
\hline İlgili ve Destek End. & 0,02 & 0,89 & 0,98 & 82 & 0,33 \\
\hline Firma Yap. Rek. ve Str. & 2,07 & 0,15 & 4,06 & 82 & 0,00 \\
\hline Devlet & 0,93 & 0,34 & $-0,49$ & 82 & 0,62 \\
\hline Şans & 0,92 & 0,34 & 0,40 & 82 & 0,69 \\
\hline
\end{tabular}

Tablo 20'den görüldüğü üzere Birimler arasında Faktör Koşulları, İlgili ve Destek Endüstriler, Devlet ve Şans faktörleri için istatistiksel açıdan anlamlı bir fark bulunmazken ( $p>0,05)$, Talep Koşulları ve Firma Yapısı Rekabet ve Strateji faktörleri arasında ise istatistiksel açıdan anlamlı bir fark olduğu tespit edilmiştir $(p<0,05)$. Bu sonuçlara göre $\boldsymbol{H 7}$ hipotezi elması oluşturan köşelerden Faktör Koşulları, İlgili ve Destek Endüstriler, Devlet ve Şans faktörleri için reddedilmiş, Talep Koşulları ve Firma Yapısı Rekabet ve Strateji faktörleri için ise kabul edilmiştir.

Üniversiteler için Talep Koşulları ortalaması ve standart hatası 3,21 $\pm 0,07$ iken, Bakanlık Araştırma Enstitüsü ortalaması ve standart hatası ise 2,91 $\pm 0,14$ olarak hesaplanmıştır. Üniversitelerin Firma Yapısı Rekabet ve Strateji ortalaması ve standart hatası 3,74 $\pm 0,06$ iken, Bakanlık Araştırma Enstitüleri ortalaması ve standart hatası ise 3,23 $\pm 0,12$ olarak hesaplanmıştır.

Elması oluşturan faktörlerin ana bilim dalları arasında farklılık gösterip göstermediğinin tespit edilmesi amacıyla tek yönlü ANOVA testi uygulanmıştır. Analiz uygulanmadan önce yapılan Levene testi sonucunda Devlet değişkeni varyansının homojen dağılmadığ $1(p<0,05)$, diğer değişkenlerin ise homojen dağıldığ $(p>0,05)$ görülmüştür. Bu nedenle Devlet faktörü için ANOVA-Tamhane, diğer değişkenler için ANOVA-Schefee testi kullanılmıştır. Test sonuçları Tablo 21'de gösterilmiştir. 
Tablo 21. Ana Bilim Dalları ile Elmas Faktörleri ANOVA testi Sonuçları

\begin{tabular}{|c|c|c|c|c|c|c|c|}
\hline \multicolumn{2}{|c|}{ Değişkenler ve Gruplar } & \multirow{2}{*}{$\frac{\text { Ort }}{3,81}$} & \multirow{2}{*}{$\frac{\text { S.H. }}{0,06}$} & \multicolumn{2}{|c|}{ Değişkenler ve Gruplar } & \multirow{2}{*}{$\frac{\text { Ort }}{3,11}$} & \multirow{2}{*}{$\frac{\text { S.H. }}{0,08}$} \\
\hline & Su Ür. Yet. ${ }^{a}$ & & & & Su Ür. Yet. ${ }^{a}$ & & \\
\hline $\begin{array}{l}\text { Faktör } \\
\text { Kosulları }\end{array}$ & Av. İş. Tek. ${ }^{a}$ & 3,80 & 0,09 & Talep Koşulları & Av. İş. Tek. ${ }^{a}$ & 3,20 & 0,12 \\
\hline & Tem. Bil. ${ }^{\mathrm{a}}$ & 3,69 & 0,18 & & Tem. Bil. ${ }^{\mathrm{a}}$ & 3,15 & 0,19 \\
\hline \multirow{3}{*}{$\begin{array}{l}\text { İlgili ve Destek } \\
\text { Endüstriler }\end{array}$} & Su Ür. Yet. ${ }^{a}$ & 2,81 & 0,08 & \multirow{3}{*}{$\begin{array}{c}\text { Firma Yapısı } \\
\text { Rekabet ve } \\
\text { Strateji }\end{array}$} & Su Ür. Yet. ${ }^{a}$ & 3,67 & 0,07 \\
\hline & Av. İş. Tek. ${ }^{a}$ & 2,86 & 0,15 & & Av. İş. Tek. ${ }^{a}$ & 3,67 & 0,08 \\
\hline & Tem. Bil. ${ }^{a}$ & 2,59 & 0,23 & & Tem. Bil. ${ }^{a}$ & 3,27 & 0,18 \\
\hline \multirow{3}{*}{ Devlet } & Su Ür. Yet. ${ }^{a}$ & 3,00 & 0,08 & \multirow{3}{*}{ Şans } & Su Ür. Yet. ${ }^{a}$ & 3,64 & 0,11 \\
\hline & Av. İş. Tek. ${ }^{a}$ & 3,21 & 0,08 & & Av. İş. Tek. ${ }^{a}$ & 3,65 & 0,22 \\
\hline & Tem. Bil. ${ }^{\mathrm{a}}$ & 3,17 & 0,22 & & Tem. Bil. ${ }^{\mathrm{a}}$ & 3,43 & 0,20 \\
\hline
\end{tabular}

Tablo 21'den görüldüğü üzere ana bilim dalları arasında elması oluşturan faktörler için istatistiksel açıdan anlamlı bir fark bulunamamıştır ( $p>0,05)$. Bu sonuçlara göre $\mathbf{H} 8$ hipotezi reddedilmiştir.

Elması oluşturan faktörlerin iş tecrübesi grupları arasında farklılık gösterip göstermediğinin tespit edilmesi amacıyla tek yönlü ANOVA testi uygulanmıştır. Analiz uygulanmadan önce yapilan Levene testi sonucunda İlgili ve Destek Endüstriler değişkeni varyansının homojen dağılmadığı $(\mathrm{p}<0,05)$, diğer değişkenlerin ise homojen dağıldı̆̆ 1 ( $>>0,05)$ görülmüştür. Bu nedenle İlgili ve Destek Endüstriler faktörü için ANOVA-Tamhane, diğer değişkenler için ANOVA-Schefee testi kullanılmıştır. Test sonuçları Tablo 22' de gösterilmiştir.

Tablo 22. Tecrübe Grupları ile Elmas Faktörleri ANOVA testi Sonuçları

\begin{tabular}{|c|c|c|c|c|c|c|c|}
\hline \multicolumn{2}{|c|}{ Değişkenler ve Gruplar } & \multirow{2}{*}{$\frac{\text { Ort }}{3,60}$} & \multirow{2}{*}{$\frac{\text { S.H. }}{0,08}$} & \multicolumn{2}{|c|}{ Değişkenler ve Gruplar } & \multirow{2}{*}{$\frac{\text { Ort }}{3,00}$} & \multirow{2}{*}{$\frac{\text { S.H. }}{0,11}$} \\
\hline \multirow{3}{*}{$\begin{array}{c}\text { Faktör } \\
\text { Koşulları }\end{array}$} & $1-10 \mathrm{y}_{1} \mathrm{a}^{\mathrm{a}}$ & & & \multirow{3}{*}{ Talep Koşulları } & $1-10 \mathrm{y}_{1} \mathrm{a}^{\mathrm{a}}$ & & \\
\hline & $11-20 \mathrm{yll}^{\mathrm{a}, \mathrm{b}}$ & 3,74 & 0,09 & & $11-20 \mathrm{y}^{1} \mathrm{l}^{\mathrm{a}}$ & 3,11 & 0,10 \\
\hline & 21 yıl ve üstü ${ }^{b}$ & 3,94 & 0,08 & & 21 yıl ve üstüa & 3,24 & 0,12 \\
\hline \multirow{3}{*}{$\begin{array}{l}\text { İlgili ve Destek } \\
\text { Endüstriler }\end{array}$} & $1-10 \mathrm{y}^{1} \mathrm{l}^{\mathrm{a}}$ & 2,56 & 0,11 & \multirow{3}{*}{$\begin{array}{c}\text { Firma Yapisı } \\
\text { Rekabet ve } \\
\text { Strateji }\end{array}$} & $1-10 \mathrm{yll}^{\mathrm{a}}$ & 3,48 & 0,13 \\
\hline & $11-20 \mathrm{y}^{1} \mathrm{a}^{\mathrm{a}}$ & 2,78 & 0,12 & & $11-20 \mathrm{y}_{1} 1^{\mathrm{a}}$ & 3,61 & 0,10 \\
\hline & 21 yıl ve üstü ${ }^{a}$ & 2,89 & 0,13 & & 21 yıl ve üstü ${ }^{a}$ & 3,62 & 0,10 \\
\hline \multirow{3}{*}{ Devlet } & $1-10 \mathrm{y}^{\mathrm{a}}{ }^{\mathrm{a}}$ & 3,14 & 0,16 & \multirow{3}{*}{ Şans } & $1-10 \mathrm{yll}^{\mathrm{a}}$ & 3,89 & 0,16 \\
\hline & $11-20 \mathrm{yll}^{\mathrm{a}}$ & 3,10 & 0,10 & & $11-20 \mathrm{yll}^{\mathrm{a}}$ & 3,56 & 0,16 \\
\hline & 21 yıl ve üstü ${ }^{a}$ & 2,98 & 0,11 & & 21 yıl ve üstüa & 3,57 & 0,15 \\
\hline
\end{tabular}

Aynı sütunda farklı üst karakterlerle ifade edilen gruplar istatistiksel olarak birbirinden farklıdır $(p<0,05)$

Tablo 22'den görüldüğü üzere tecrübe grupları arasında Faktör Koşulları için istatistiksel açıdan anlamlı bir fark bulunmuş $(p<0,05)$, diğer faktörler için ise 
istatistiksel açıdan anlamlı bir fark bulunamamıştır ( $p>0,05)$. Bu sonuçlara göre $\mathbf{H 9}$ hipotezi elması oluşturan köşelerden Talep Koşulları, İlgili ve Destek Endüstriler, Firma Yapısı Rekabet ve Strateji, Devlet ve Şans faktörleri için reddedilmiş, Faktör Koşulları faktörü için ise kabul edilmiştir.

\section{SONUÇ VE TARTIŞMA}

Bu çalışmada, Türkiye'nin su ürünleri yetiştiriciliği sektörünün uluslararası rekabetçilik düzeyinin Porter (1990)'ın Elmas modeli ile akademisyenlerin bakış açısından açıklanabilirlik seviyesini tespit etmek amaçlanmıştır. Böylelikle sektörün rekabetçilik düzeyinin ve rekabet yapısının temel özellikleri ortaya konması ve uluslararası pazar payının arttırılmasına yönelik stratejilerin geliştirilmesine katkı sağlanması hedeflenmektedir.

Çalışmaya katılanların ortalama yaşı 42,84 ve ortalama iş tecrübeleri ise 18,19 yıldır. Katılımcıların \% 88,10'unun lisansüstü derecesi mevcut olup, \% 66,66's1 ise doktora mezunudur. Anketi dolduranların \% 76,19'u da su ürünleri mühendisi veya balıkçılık teknolojisi mühendisidir. Bu nedenle katılımcıların sektör ile ilgili yeterli bilgi ve tecrübeye sahip oldukları ve stratejik bir bakış açısıyla önermelere cevap verebilecekleri kanısına varılmıştır. Ayrıca örneklemin yarısından fazlası hangi üniversite ya da araştırma enstitüsünde çalıştığını belirtmiş olup, bunların da Üniversitelere orantılı bir şekilde dağıldığı görülmüştür.

Porter (2013: 64), sektör rekabetini şekillendiren beş kuvveti Sektöre Yeni Giriş, Alıcıların Gücü, Tedarikçilerin Gücü, Firmalar Arası Rekabet ve İkame Ürünlerin Etkisi olarak belirtmiş ve bir işletmenin bu rekabet kuvvetlerine karşı kendilerini savunmak ve onları işletmenin lehine çevirebilmek strateji geliştirebilmek açısından oldukça önemli olduğunu belirtmiştir. Araştırma sonuçlarına göre katılımcılar açısından rekabeti etkileyen kuvvetlerden en önemlisi Firmalar Arası Rekabet olmuştur $(3,64)$. Balıkçılık ve Su Ürünleri Genel Müdürlüğü (2016) verilerine göre hali hazırda sektöre yaklaşık 2500 adet yetiştiricilik tesisi faaliyette olup, üretimin genelde çipura, levrek ve alabalık türlerinde yaygınlaşması, üretimin neredeyse tüm işletmelerde standardize edilmiş olması gibi nedenlerle firmalar arasındaki rekabet sektörde yoğun olarak hissedilmektedir. Ayrıca çalışmanın sonuçlarına göre rekabeti etkileyen kuvvetlerden en önemsizi ise Sektöre Yeni Giriş $(2,63)$ olmuştur. Sektöre yeni firmaların girişinin rekabetteki etkisinin düşük olması, yeni bir işletme kurmanın gerektirdiği bürokratik yük (yer kiralama, ruhsat ve izin işlemleri, ÇED süreci vb.), bazı bölgelerde çevre mevzuatları nedeniyle üretim yapılamaması gibi nedenlerle açılanabilir. Yapılan istatistiksel analizlerde gerek üniversiteler-araştırma enstitüleri ve gerekse ana bilim dalları arasında istatistiksel açıdan anlamlı bir fark tespit edilememiştir. Bu durumda akademisyenlerin rekabeti etkileyen kuvvetler için görüş birliği içerisinde oldukları söylenebilir. Ancak Tedarikçilerin Gücü ve Sektöre Yeni Giriş değişkenleri için tecrübe grupları arasında istatistiksel açıdan farklılık tespit edilmiştir. Bu açıdan bakıldı̆̆ında süre bakımından farklı tecrübeye sahip akademisyenlerin bu iki değişkene farklı açıdan baktığı söylenebilir. 
Uzmanoğlu ve Arlsan (2017: 424), yapmış oldukları çalışmada akademisyenlere göre rekabeti etkileyen kuvvetlerden en önemlisinin Tedarikçilerin Gücü ve en önemsizinin ise İkame Ürünlerin Etkisi olduğunu bildirmişlerdir. Ayrıca, araştırma enstitüsü çalışanlarına göre rekabeti etkileyen kuvvetlerden en önemlisinin Alıcıların Gücü ve en önemsizinin ise İkame Ürünlerin Etkisi olduğunu tespit etmişlerdir. Bu çalışmada ise İkame Ürün Etkisi en önemli ikinci faktör olup Uzmanoğlu ve Arslan (2017)'nin çalışmasından farklılık göstermektedir. Bu konu ile ilgili yapılan çalışmaların azlığı göz önüne alındığında yapılacak yeni çalışmalarla konunun daha da derinlemesine incelenebileceği anlaşılmaktadır.

Araştırmaya katılanların görüşlerine göre sektörün kar marjının düşük ile orta arasında ancak ortaya oldukça yakın olduğu tespit edilmiştir.

Porter (2015: 42)'a göre; beş rekabet kuvvetiyle başa çıkmak ve sektördeki diğer rakipleri devre dışı bırakabilmek için uygulanabilecek üç genel strateji yaklaşımı Toplam Maliyet Liderliği, Farklılaştırma ve Odaklanma'dır. Katılımcılardan elde edilen verilere göre su ürünleri yetiştiriciliği sektöründeki bir firmanın sektörde rakiplerine göre başarı elde edebilmesi için seçmesi gereken jenerik strateji yaklaşımının Farklılaştırma olması gerektiği anlaşılmıştır. Kar marjı ve Rekabet Stratejisi ile ilgili olarak yapılan istatistiksel analizlerde, gerek üniversiteler-araştırma enstitüleri, gerek ana bilim dalları ve gerekse tecrübe grupları arasında istatistiksel açıdan anlamlı bir fark tespit edilememiştir. Bu durumda akademisyenlerin bu iki değişken için görüş birliği içerisinde oldukları söylenebilir. O halde kar marjının düşük ve orta olduğu sektörlerde sektördeki firmaların maliyet liderliği pozisyonunu alabilecekleri düşünüldüğünde, akademisyenlerin bakış açısıyla ürün veya üretim sürecini farklılaştıran işletmelerin rekabetçilik açısından bir fark yaratabileceği değerlendirilmiştir. Ayrıca rekabeti şekillendiren faktörlerin en önemlisinin firmalar arası rekabet olduğu düşünüldügünde, ürün veya üretim sürecini farklılaştıran işletmelerin rekabet gücünün artacağı düşünülmektedir.

Su ürünleri yetiştiriciliği sektörünün gelecekte miktarının nasıl değişeceğine ilişkin beklenti ise aynı kalır ile artar arasında ancak artara çok yakın olduğu görülmektedir. Gelecek beklentisi değişkeni için yapılan istatiksel analizlerde gerek birimler arasında, gerekse ana bilim dalları arasında istatistiksel açıdan önemli derecede farklılıklar tespit edilmiştir. Böylelikle sektörün gelecekteki miktarı için akademisyenler açısından görüş birliği sağlanamadığ1 düşünülmüştür. Dolasıyla sektörün gelecekteki durumunun ne olacağına ilişkin farklı değişkenler ışığında açıklayabilecek modellerle tahmin edileceği çalışmaların yapılmasının gerekli olduğu kanısına varılmıştır.

Çalışmada elması oluşturan faktörlerden en önemlisi Faktör Koşulları $(3,79)$ olmuştur. Ülkemiz gerek deniz gerekse iç sular açısından ciddi bir üretim potansiyeline sahiptir. Bunun yanı sıra, bu konudaki üniversiteler ve araştırma enstitüleri varlığı ile hem insan kaynakları hem de bilimsel ve teknik alt yapı konularında avantajlı bir konuma sahiptir. Ancak sektördeki işletmelerin birçoğunu KOBİlerin oluşturduğu göz önüne alındığında yeterli sermaye olanaklarının (kredi ve 
desteklemeler) arttırılmasının faydalı olacağı düşünülmektedir. Faktörlerden en düşüğü ise İlgili ve Destek Endüstriler $(2,78)$ olmuştur. Özellikle akademisyenlerce işletmelerin kooperatifleşme veya üretici birlikleri çatısında örgütlenmelerinin, üniversite-sektör iş birliğinin ve sektör içindeki bilgi akışının oldukça az olduğu düşünülmektedir. Dolasıyla bu noktadaki eksikliklerin giderilmesi ile sektör rekabetçiliği daha üst noktalara taşınabilir.

Ayrıca Talep Koşulları'nı oluşturan önermelerden iç talepteki tüketim miktarının yetersizliği oldukça ön plana çıkmaktadır. Devlet faktörünü oluşturan önermelerden bilgilendirme politikaları ise katılımcıların yetersiz gördüğü bir başka önermedir. Ülkemizde kişi başına düşen su ürünleri tüketim miktarları hem Avrupa hem de Dünya ortalamasından oldukça geridedir. Kaldı ki bu miktarlar içerisinde özellikle iç piyasada tüketilen avcılık ürünlerinin de dahil olduğu unutulmamalıdır. Su ürünleri yetiştiricilik ürünleri avcılık sezonu dışında kalan dönemde de piyasaya sunulabildiğinden aslında her dönem tüketicinin kolayca ulaşabileceği bir üründür. Ancak kamuoyunda yetiştiricilik ürünlerinin doğal olmadığına dair oluşmuş yanlış alg1 bu ürünlere olan ilginin azalmasına neden olabilmektedir. Bu nedenle genelde su ürünleri yetiştiriciliği ürünlerinin tüketimini arttırmak sektör rekabetçiliğinin arttırılması açısından oldukça gereklidir. Bunun için ise özellikle balık tüketiminin sağlıklı ve dengeli bir beslenme açısından önemini vurgulayan kamu spotlarının yaygınlaştırılması önerilebilir. Ayrıca yetiştiricilik ürünlerinin sağlıksızlığı konusundaki yanlış algıyı değiştirecek bilgilendirme politikalarına da ihtiyaç vardır. Beslenme alışkanlıkları temellerinin daha çocukluk yıllarında oluştuğu göz önüne alındığında okul öncesi eğitimden başlanarak balık ve su ürünleri tüketimi alışkanlıklarının arttırılmasını amaçlayan projeler üretilebilir. Tüm bunların yanı sıra, avcılık sezonu dışında da tüketicilere arz edilebilen su ürünleri yetiştiriciliği ürünlerin toplam su ürünleri tüketim miktarındaki yerinin ne olduğunun bilinmesi alınacak tedbirlerin etkinliği açısından da araştırılması gereken bir başka konu olarak karşımıza çıkmaktadır.

$\mathrm{Bu}$ çalışmada akademisyenlerin bakış açısıyla sektörün rekabetçilik düzeyi açıklanmaya çalışılmıştır. Sonuç olarak su ürünleri yetiştiriciliğinin rekabetçilik düzeyine bütüncül bir yaklaşım sergileyebilmek için sektörde yer alan işletmeler, sivil toplum kuruluşları ve mevzuat düzenlemeleri ve kontrollerden sorumlu kuruluşlar gibi paydaşların bakış açılarının da ortaya konulması ihtiyacının olduğu düşünülmektedir. Böylelikle ülkemiz su ürünleri yetiştiriciliği sektörünün rekabetçiliği tüm paydaşlar açısından değerlendirilebilecek, paydaşların arasındaki bakış açısı farklılıkları ortaya konabilecek ve böylelikle daha verimli önerilerde bulunulabilecek ve kuruluşlar açısından strateji geliştirilmesine katkı sağlanmış olacaktır. 


\section{KAYNAKÇA}

Aktan, C. ve Vural, C. (2004) Rekabet Gücü ve Türkiye, Ankara: TiSK Yayını Rekabet Dizisi:3.

Altuntaş, F. F. ve Karakaya, A. (2017) “Öğretmenler Açısından Hukuksal Farkındalığın Psikolojik Tacize Etkileri" Karabük Üniversitesi Sosyal Bilimler Dergisi, Yıl:2016, Özel Sayı:2:177-201.

Bakan, İ. ve Doğan, İ. F. (2012) “Competitiveness Of The Industries Based On The Porter's Diamond Model: An Emphrical Study" International Journal of Research and Reviews in Applied Science, 11(3):441-455.

Bulu, M., Eraslan, İ. H. ve Kaya, H. (2006) “Türk Elektronik Sektörünün Rekabetçilik Analizi” İstanbul Ticaret Üniversitesi Sosyal Bilimler Dergisi, 5(9):49-66, 2006/1.

Bulu, M., Eraslan, İ. H. ve Barca, M. (2007) "Türk Gıda Sektörünün Uluslararası Rekabetçilik Düzeyinin Analizi" Afyon Kocatepe Üniversitesi İ.I.B.F. Dergisi, 9(1):311-335.

Çivi, E. (2001) “Rekabet Gücü: Literatür Araştırması” Celal Bayar Üniversitesi İ.İ.B.F. Yönetim ve Ekonomi Dergisi, 8(2):21-38.

Demir, E., Saatçioğlu, Ö. ve İmrol, F. (2016). “Uluslararası Dergilerde Yayımlanan Eğitim Araştırmalarının Normallik Varsayımları Açısından İncelenmesi" Current Research in Education, (2016), 2(3):130-148.

Eraslan, İ. H., Bakan, İ ve Kuyucu, A. D. H. (2008) “Türk Tekstil ve Hazırgiyim Sektörünün Uluslararası Rekabetçilik Düzeyinin Analizi" İstanbul Ticaret Üniversitesi Sosyal Bilimler Dergisi, 7(13):265-300.

FAO (2016). Food and Agriculture Organization of the United Nations Statistics Division (21.06.2016).

Gökmenoğlu, S. M., Akal, M. ve Altunışık, R. (2012) “Ulusal Rekabet Gücünü Belirleyen Faktörler Üzerine Değerlendirmeler" Rekabet Dergisi, 13(4):3-43.

Gürpınar, K. ve Sandıkçı, M. (2008) “Uluslararası Rekabetçilik Analizinde Michael E. Porter’ın Elmas Modeli Yaklaşımı: Türkiye'deki Bazı Endüstrilerdeki Uygulanabilirliğinin ve Sonuçlarının Araştırıması" Sosyal Ekonomik Araştırmalar Dergisi, 1(15):105-125.

Koç, M. ve Özbozkurt, O. B. (2014) “Ulusların Rekabet Üstünlüğü ve Elmas Modeli Üzerine Bir Değerlendirme" İşletme ve İktisat Çalışmaları Dergisi, 2(3):85-91.

Nderitu, M., W. (2012) Assessing The Competitiveness of Tourism Industry in Kenya Using Porter's Diamond Model. University of Nairobi Business School Business and Administration Master Thesis.

Markus, G. (2008). "Measuring company level competitiveness in Porter's Diamond model framework." In FIKUSZ 2008 Business Sciences-Symposium for Young Researchers: Proceedings (pp. 149-158).

Mboya, J. and Kazungu, K. (2015) "Textile and Apparel Industry in Tanzania: The Application of Porter's Diamond Model" British Journal of Economics, Management \& Trade, 7(2):128147.

Özer, K. O. (2012) Türk Turizm Endüstrisinin Uluslararası Rekabet Gücünün Değerlendirilmesi: Elmas Modeli ile Türkiye İspanya Karşılaştırması. T.C. Sakarya Üniversitesi Sosyal Bilimler Enstitüsü Doktora Tezi. 
Pawar, P. A. and Veer, N. B. (2014) "Competitive Advantage of India for FDI in Retail: A Porter's Diamond Approach" Annual Research Journal of Symbosis Centre for Management Studies, Vol:1, January 2013- January 2014, pp:69-83.

Porter, M.E. (1990) The Competitive Advantages of Nations: with a new introduction The Free Press ISBN0-684-84147-9.

Porter, M.E. (2013) Stratejiyi Şekillendiren Beş Rekabet Kuvveti, Harward Business Review's 10 Must Reeds Strateji. Optimist Yayınları, Yayın No:341, Temmuz, 2013.

Porter, M.E. (2015) Rekabet Stratejisi. Aura Kitaplığı, Sertifika No: 12761, Eylül 2015.

Riasi, A (2015) "Competitive Advantages of Shadow Banking Industry: An Analysis Using Porter Diamond Model" Business Management and Strategy, 6(2):15-27.

Rodrigues, G. and Kahn, Z. R. (2015). “Competitiveness of Clothing Industry Based on Porter's Diamond Model:SAFTA Countries" Proceedings of Academic World International Conferane, International Institue of Engineers and Researchers, United States, pp:18-23.

Razali, N.M. and Wah, Y.P. (2011). "Power comprasions of Shapiro-Wilk, Kolmorogov-Smirnov, Lilieforcs and Anderson-Dalling tests" Journal of Statistical Modeling and Analytics. 2011, 2(1):21-33.

Sarı̈ozkan, S. (2016). “Türkiye'de Balıkçılık Sektörü ve Ekonomisi” Turkish Journal of Aquatic Sciences. 31(1): 15-22.

Salvucci, S., Walter, E., Conley, V., Fink, S. And Saba, M. (1997). Measurement Error Studies at the National Center for Education Statistics (NCES). Washington D.C. U.S. Department of Education. NCES 97-464.

Süygün, M. S. (2013) Uluslararası Rekabet Gücü Olarak Kümelenme: Mersin Yaş Meyve Sebze Kümesi Örneği. T.C. Çukurova Üniversitesi Sosyal Bilimler Enstitüsü İşletme Bölümü DoktoraTezi.

Tavakol, M. and Denninck, R. (2011). "Making sense of Cronbach's alpha" International Journal of Medical Education, 2011; 2:53-55. ISSN:2042-6372.

TÜIK (2016). Türkiye İstatistik Kurumu Verileri (21.06.2016).

Yazıcıoğlu, Y. ve Erdoğan, S. (2014). SPSS Uygulamalı Bilimsel Araştırma Yöntemleri Detay Yayıncilık Yayın No:091 ISBN 978-975-8326-98-3.

Uzmanoğlu, M. S. ve Arslan, F. M. (2017). “Deniz Balığ1 Yetiştiriciliği Sektöründe Rekabet Algısı: Türkiye Üzerine Bir Araştırma" Yunus Araştırma Bülteni, 2017(4):413-428.

Ülgen, H. ve Mirze, S.K., (2013). İşletmelerde Stratejik Yönetim Beta Yayıncılık İşletme-Ekonomi Dizisi:651, Nisan 2013. 